\title{
小児における下部尿路のレ線学的研究
}

\author{
金沢大学医学部泌尿器科教室 \\ （主任：黑田恭一教授） \\ 大学院学生 島 \\ 木

\section{ROENTGENOLOGICAL STUDY OF .THE LOWER URINARY TRACT IN CHILDHOOD}

彰

\author{
Akira Shimaki \\ From the Department of Urology, School of Medicine, Kanazawa University \\ (Director: Prof. K. Kuroda)
}

By delayed cystography in 76 cases, voiding cystography in 19 cases and urethrocystography in 88 cases, the author made a morphological observation on the normal case and many urological diseases, especially enuresis.

By delayed cystography, the vesicoureteral reflux (VUR) was minutely observed, and incidentally the cystogram was also examined.

The rate of the occurrence of VUR is $11.9 \%$, and it is very high in case of the infection of the urinary tract. VUR appears in three types: the immediate type, the continual type and the delayed type. There is no relation between VUR and residual urine, cystoscopic and cystometric findings. As compared with intravenous pyelogram, the rate of functional decrease of the upper urinary tract is $1 / 3$ on the side showing VUR.

By the continuous observation of cystograms in the course of time, which shows the process of physiological filling of the urinary bladder, the situation of the bladder floor is constant, and the cystogram, which is semilunar and semicircular when the bladder is empty, is most remarkably dilated to the vertical direction, and as a whole it is radiately dilated. The ratio of vertical and horizontal dilation is within $1.2-1.5$ for an hour, and as long as the patient doesn't feel a desire to void, the maximum of vertical diameter is not longer than that of horizontal one. The more the age advances, the more the situation of the whole cystogram descends.

Both the funnel projection of the bladder neck which was observed by delayed cystography and the dilation of the bladder neck and the internal orifice by voiding cystography are the characteristic findings in case of enuresis.

As a result of the observation which was made from the view point of the aging in measuring many urethral portions of the male infants and children by urethrocystography, the prostatic urethra does not grow so remarkably in childhood, but rapidly develops since puberty. And yet the other portions grow nearly in proportion to the development of total constitution.

The supracollicular portion is classified into four types by urethrocystography, and among them the dilated type was often found in enuresis.

By measuring radiation dose (to the gonads and the skin) by each roentgenography, it was approved to be very effective to protect the gonads of the patient by the use of the lead plate $1 \mathrm{~mm}$ thick.

\section{I 緒言}

幼小児の排尿異常は一般に考えられている程稀有なも のでないが, その臨床像柱成人の排尿異常と自ら異なる 点がある．特汇患者自身が排尿異常を訴えない為に，正 常の意識的排尿調節の始まる 3 才頃までは両親もかかる 排尿異常の存在化気付かず, 先天性排尿異常の子供怡そ の儘成長した後も排尿異常の自覚がなく, 叉 3 才以後の 山供でもその訴えの暧昧なとと,おふびその殆どが尿失
禁の症状を呈するので観察者住単なる遺尿症と片付けて 安易な考えから放置する場合が多い，しかして所謂尿失 禁の根底にある排尿困難一慢性尿閉一上部尿路疾患の存 在はともすれば見逃され易い。

近時, 小児泌尿器科学の進歩と共に, 内視鏡的あるい はレ線学的にその原因が検索されつつあるが, 内視鏡検 査治患者の協力が余り望めず施行困難があり，ために容 易に実施され, 患者の協力も得られるレ線学的検查方法 
による趨势にある。特に小児では延引性膀胱撮影 (delayed cystography, 以下延引性撮影々略記), 排尿時尿 道膀胱撮影 (voiding urethrocystography, 以下排尿時 撮影と略記) を中心に盛んに研究が行なわれている.

延引性撮影に上る膀胱尿管逆流現象の研究は, Stewa$\mathrm{rt}^{922}$ が1948年に創始して以来, Bunge ${ }^{7>8)}$, Lattimer et al. ${ }^{68)}$, Jones \& Headstream ${ }^{55)}$, Martin et al. $^{78)}$, Fulton ${ }^{23)}$, Burns et al. ${ }^{10)}$, Forsythe \& $\mathrm{Wealan}^{24)}$, Leuzinger et al. ${ }^{69)}$, Christensen ${ }^{16)}$ によ種々改良され て行なわれ，本邦では黒田 ${ }^{61)}$ (1956) が始めて遅延膀胱 撮影法已称して報告し, 以後延引性膀胱撮影法と呼んで いる. これは造影剤を膀胼内へ注入し，一定時間保持せ しめ, 一定間隔の下に膀胱撮影を反覆施行する方法で, 目的とするところは一定の時でなく永続的な尿管膀胱生 理の放射線学的研究である. Rubin \& Snoble ${ }^{83)}$ は器械 的操作不能の幼児に特に有用であると云い，Fulton ${ }^{23)}$ は従来の方法では診断の困難な症例に対する有力な補助 診断法として重要視している.

次に幼小児の尿道膀胱撮影は殆どすべてが排尿時尿道 膀胱撮影によつて抢り，1944年 Brodny \& Robins ${ }^{4)}$ が 遗尿症患者の注入時尿道撮影を報告している以外は，尿 道疾患あるいは膀胱疾患の症例に施行されているにすぎ ない。

私怡小児を対象に延引性撮影，排尿時撮影を追試して 外国の報告と比輘検討すると共に，従来余り注目されな 方つた膀胱像の変化を観察し, 併せて逆行性尿道膀胱撮 影を行ない，尿道の年令的発育状況㧍よび形態的変化に ついて研究した.

\section{II. 解剖学的事項}

$\mathrm{Kopsch}^{59)}$ 快膀胱を底部，頂部，体部の 3 部に分けて いるがX線写真上ではその区分は不能である．適度に充 満された膀胱は底部が水平て前方に45度の角度を有し， 立位と臥位では立位の方が臥位より前傾するが，膀胱内 容の増加に伴い臥位でも同様の所見が得られるとし， Sgalitzer \& Hryntschak ${ }^{85}$ によれば内尿道口は膀胱最下 点に存在するが，立位では排尿直前むで恥骨の直後に相 当する部が最も低いと述べている.

解剖学的に膀胱筋層は前後面に発達して上方ょり下方 へ S 字状に走行し互いに交錯する外側縦走筋と, 輪状不 規則網状に走行し全膀胱に拡がる菲薄な中層輪状筋と， 両側尿管口ょり男子の精丘部，女子の外括約筋まで連続 して特に膀胱三角部に上く発達した縦走の互いに交刃網 状を形成する内側縦走筇の 3 層よりなつている，Wes- $\operatorname{son}^{106)}$, Van Duzen \& Duncan ${ }^{104)}$ 仙前二者と後者と を発生学上区別し夫々独立したものとしている. 然し Hunter ${ }^{48)}$, Henningsen ${ }^{36)}$ は三者いずれも外側筋層の連 続で, その筋束は上方から下方へ $\mathrm{S}$ 字状に, 外側から内 側へ螺旋状に走行しているにすぎないと述べている。い ずれにせょ極めて精巧な網状構造を有して伸縮性に富 み, 膀胱内圧に抵抗せず尿の貯溜排泄器官としての使命 を果している。

尿管筇層は内層縦走筋層と外層輪状筋層よりなり下部 尿管に注更に外層縦走筋層が存在する. 膀胱と尿管との 関係は，尿管下部が膀胱壁学側上方より内下方へ斜めに 貫通して膀胱壁内尿管を形成し，その長さは 1.2〜 2.0 $\mathrm{cm}$ で，膀胱壁とのなす角度注成人では鈍角 ( 110 度), 幼 若者で流直角又は鋭角を示す。 Marshall ${ }^{79)}$ は壁内尿管 の直径と長さとの比は $1: 6$ ～7であると述べている. この壁内尿管部で輪状筋層は消失し内外縦走筋の間は粗 な結合織で分隔せられ，その結合織は尿管を囲絖して， ここに Waldeyer 鞘を形成し, 尿管運動の独自性を保 護する. Kopsch ${ }^{58)}$ は Waldeyer 鞘は膀胱筋の一部で尿 管を管状に包囲すると説いている。

Elliot $^{19)}$ によれば後部尿道は膀胱䅡部より泌㽷生殖器 隔膜まで環状縦走の平滑筋で取囲まれ，膀胱之前立腺の 間でその筋線維数を増して内括約筋を形成する．Muschat ${ }^{73)}$ 注内括約筋は馬蹄形を呈し, その前面には特に括: 約筋伀見られないと記載し, Vernet ${ }^{105)}$ は内括約筋は前 後 2 万向から馬蹄形の筋組織で形成され, 即与前面より 利尿筇の係蹄に属する筋線維が後部へ凹を向けた馬蹄形 で内尿道口部に存在し, 後面には三角部係蹄汇属する弓 形筋線維が前部へ凹を向けて存在し, 両者で完全に内尿 道口部を囲絖して強力な括約筋作用を営むと述べてい る. Kjellberg et al. ${ }^{64)}$ は内括筇約は男性女性共に主と して強力な円錐形笳線維の trigonal region を作り, 前 方に拡がり内尿道口を囲みながら前立腺部尿道の上 ${ }^{2} / 3$ まで達するとし, 小見山 ${ }^{65}$ ( $は$ 内尿道口附近の膀胱筋は内 層の縦走筋が輪状をとつて後壁の中央に膀胱眊垂を形成 し, 更に延長して内尿道口筋の主要筋となり, 頚部附近 で輪状の中層筋が一部入り内外の縦走筋と相俟つて肥厚 し, その筋束が頚部側面へ半螺损状汇のび内尿道口を因 絖して括約筋となると記載している.

Beneventi \& Marshall9) は7才，12才，19才，40才 の 4 人の正常男子尿道を検索し, 外括約筋線維による環 は前立腺被膜の下部少くとも数mm形成し, 漸次線維数 を減じて前立腺底部で消失するが，若年者程膀胱罆部附 
近まで達していると述べ，Wesson ${ }^{105)}$ の記述する外括約 筋線維が膀胱䅡部附近の前立腺の側面から始まると云う 考えを否定し，背面が最も線維束に富み両側には殆ど無 いとしている.

Morales \& Romanus ${ }^{7677)}$ (前部尿道と後部尿道との 境界である泌尿生殖器隔膜の下部は骨盤底筋収縮時尿道 撮影により造影剤の円錐の尖端として示され，ての円錐 の少し下方で尿道前壁の内弯が見られ, その部に腱板が 存在するととをレ線学的に証明し, その筋肉を $\mathrm{M}$. compressor nudae と称し, 又前部尿道の最中心側怡筋 肉抢よび海綿体組織で蔽われていないとしてその部を裸 部 (Pars nuda) と命名している. 更に外括約筋は前立 腺の側方を走り，漸次その線維束を增して前立腺の下で 後下方へ傾斜しながら尿道を完全に取巻いていると述べ ている.

膀胱怙よび尿道の神経支配は一般に次のように考えら れている.

胸䯣XII, 腰檤 I, II ๖り出た交感神释法下腹神経叢と なり膀胱に達する. Kjellberg et al. ${ }^{64)}$ とよればこの交 感神経恃尿管, Bell 筋, 膀胱三角部, 尿道を支配する とし, Wesson ${ }^{106}$ ) は下腹神経の刺战で三角部, 尿道の収 樎を来たし，その遮断により膀胱の緊張を增し自律反射 の消失を伴う永続性収縮を来たしたと述べている。

仙䯣 II 〜 IV りで副交感神経は勃起神経, 骨盤神経. を経て膀胱, 尿道, 海綿体の平滑筋を支配し, Kjellberg et al. ${ }^{64)}$ 怔副交感神経障害仙利尿筇の緊張低下の為に 排尿が強く障害されて膀胱を空虚にすることが出来ず, 一側の刺战では一側のみが収縮すると説いている.

仙髄 II 〜IVより出た陰部神経は尿道の横紋筋主に外括 約筋を支配し, Kjellberg et al. ${ }^{64)}$ はこの陰部神経の遮 断は外括約筋の弛緩を来たし, その刺战は外括約筇の収 縮を来たすとし，外括約筋は随意的に閉じるが随意的に 開かず, 膀胱筋が収縮し膀胱碩部が開いた後, 初めて開 くことを記述している.

\section{III 撮影術式}

\section{A）延引性膀胱撮影}

被検者に排尿させた後ネラトンカテーテルを挿入して 残尿を測る. 次いで体温程度に温めた隇菌水を注入して 膀胱容量を測定し, その約 $1 / 3$ 量の造影剂 (33\% Sugiuron 又梳 2 倍稀釈 Sugiuron) を徐々に 1 分間 5 〜 10cc の速度で膀胱内へ注入し, ネラトンカテーテルを抜去す る. その直後に仰臥位にして下肢を伸展させ第 1 回撮影 运行なう. 更に 30 分後, 60 分後に同様の体位て第 2 回,
第 3 回撮影を行な3.X線装置は東芝 KXO-8 型, 管球 は XDO-R-70 を使用 (以下同様), 管球の焦点法恥骨上 縁と臍部の中間で正中線上に垂直に掞き，1 mの高さに 管球を保ち，管電圧 $62 \mathrm{KV}$ ，管電流 $150 \mathrm{~mA}$, 時間 0.3 sec の条件で撮影した。

被検者は各撮影間には自由に歩行せしめるが, 非協 力的な幼児の場合にはネラトンカテーテルを留置したま $>$, その先端を造影剤の流出しないように止めておき, 又尿意の強い場合法最大尿意時に撮影し, その後排尿さ せた。小児では性腺保護が特に問題となるので，男児の 場合は厚さ $1 \mathrm{~mm}$ の鉛板で陰囊部を遮蔽したが，女児では 性腺が撮影部位と重なるため防護が出来なかつた。

B) 排尿時尿道膀胱撮影

延引性撮影終了後, 被検者を立位第 1 斜位にし, 管球 を水平位に廻転して焦点が恥骨上縁と臍部の中間で正中 線より 1 横指左側に当るようにし， $1 \mathrm{~m}$ の距離に管球を 固定する. 被検者に排尿を命じ, タイミングを合わせつ つ、管電圧 $68 \mathrm{KV}$ ，管電流 $150 \mathrm{~mA}$, 時間 $0.2 \mathrm{sec} の$ 条 件で撮影した。

C) 逆行性尿道膀胱撮影

撮影前に被検者に排尿させ，尿道粘膜麻酔の目的で 2 \% Novocain 5 10ccを尿道内に注入して約 5 分間保持 させる. 次いで45度の支持台を装備した撮影台上に正確 に45度第 1 斜位で固定し, 造影剂 (Pyraceton C) 10 15ccを, 外尿道口はり徐々にしかも連続的に注入しなが ら第 1 回の撮影を行ない (注入時撮影), 次に $2 \sim 3 \mathrm{cc}$ 造 影剤を追加注入し骨盤底筋収縮を命じて第 2 回撮影を行 ない (収縮時撮影), 更に注入終了後外尿道口部を把持し たま〉の状热で，1分後抢よび 2 分後に撮影した（注入 後 1 分, 同 2 分撮影).

造影剤の注入には漏出を防ぐ目的で $20 \mathrm{cc}$ 注射器に約 3 cmの細いネジトンカテーテル（４５番）の先端を連結 した器具を使用した。撮影条件は管電压 $68 \mathrm{KV}$, 管電流 $150 \mathrm{~mA}$, 時間 $0.2 \mathrm{sec} て ゙$. この場合も性腺保護の目 的で陰囊部学厚さ $1 \mathrm{~mm}$ の鉛板で遮蔽した。

\section{IV. 成縝}

A) 延引性膀胱撮影

検査対象注14才以下の幼小児76例よりなり, 男児, 女 児各38例である．その年命分布扝よび疾患別分類を表示 すると第 1 表，第 2 表の如くて，疾患では遗尿症と尿路 感染症が圧倒的に多く過半数を占める.「その他」の内 訳沬包茎 4 例，尿道異物 1 例，神経性頻尿 4 例。停留睪 
第 1 表

\begin{tabular}{|c|c|c|c|}
\hline 年 令 & 男 & 女 & 計 \\
\hline 1 & & 1 & 1 \\
\hline 2 & & & \\
\hline 3 & 1 & 2 & 3 \\
\hline 4 & & 3 & 3 \\
\hline 5 & 2 & 2 & 4 \\
\hline 6 & 4 & 3 & 7 \\
\hline 7 & 5 & 4 & 9 \\
\hline 8 & 4 & & 4 \\
\hline 9 & 4 & 4 & 8 \\
\hline 10 & 6 & 4 & 10 \\
\hline 11 & 5 & 4 & 9 \\
\hline 12 & 4 & 4 & 8 \\
\hline 13 & 1 & 4 & 5 \\
\hline 14 & 2 & 3 & 5 \\
\hline 計 & 38 & 38 & 76 \\
\hline
\end{tabular}

丸 1 例, 膀胱三角部異常症 1 例である.

1) 膀胱尿管逆流現象 (vesicoureteral reflux: VUR 之略記)について
第 2 表

\begin{tabular}{|c|c|c|c|}
\hline 疾 患 名 & 男 & 女 & 計 \\
\hline 遺 尿 症 & 21 & 15 & 36 \\
\hline 尿 路 感 染 症 & 10 & 15 & 25 \\
\hline 神 経 因性膀脱 & 0 & 2 & 2 \\
\hline 尿 路 結 石 症 & 0 & 1 & 1 \\
\hline の & 7 & 4 & 11 \\
\hline 泌尿器科的正常例 & 0 & 1 & 1 \\
\hline 計 & 38 & 38 & 76 \\
\hline
\end{tabular}

76例の延引性撮影に执いて VURの認められた症例は 9 例（男児 5 例，女児 4 例）で，その疾患名执よび諸検 查成績を示すと第 3 表の如くである. 尿路感染症が 4 例 で最も多く, 次いで遺尿症, 真性包茎の各 2 例, 神释因 性膀胱 1 例となつている. 残尿は 9 例中 6 例に認めら れ, 静脈注射腎孟撮影を 8 例に施行した結果, 正常側に VUR を認めたものが 5 例あり，膀胱鏡検查では 1 例に 高度の肉柱形成招よび発赤， 1 例に発赤を認め，5 例㤝 正常で，2例は施行不能であつた。膀胱内圧測定検查は 9 例中 5 例に行ない, 緊張過度膀胱 2 例, 緊張低下膀胱

第 3 表

\begin{tabular}{|c|c|c|c|c|c|c|c|c|c|c|c|c|c|c|}
\hline 症例 & $\mid \begin{array}{l}\text { 年令 } \\
(\text { f }\end{array}$ & 性 & 診断 & $\left|\begin{array}{|}\text { 容胱 } \\
\text { 膀 } \\
\text { (cc) }\end{array}\right|$ & & 直 後 & 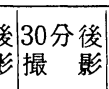 & \begin{tabular}{|l}
60 分後 \\
撮 影
\end{tabular} & 尿 所 見 & $\begin{array}{l}\text { 腎盎 } \\
\text { 撮影 }\end{array}$ & $\begin{array}{l}\text { 䏽胱 } \\
\text { 鏡所 } \\
\text { 見 }\end{array}$ & $\mid \begin{array}{l}\text { 膀胱 } \\
\text { 内压 } \\
\text { 検查 }\end{array}$ & 治 & 備 \\
\hline 1 & 8 & 男 & 遗尿症 & 120 & 28 & 左 (III) & )左 (III) & $(-)$ & 正 & & & & & $\begin{array}{l}\text { 排尿時撮影で V U } \\
\mathrm{R}(-)\end{array}$ \\
\hline 2 & 7 & 男 & \begin{tabular}{|l|} 
急性膀 \\
脂炎
\end{tabular} & $\begin{array}{r}60 \\
100\end{array}$ & $\begin{array}{c}12 \\
3\end{array}$ & $\begin{array}{l}\text { 右( I ) } \\
(-)\end{array}$ & & & $\left\{\begin{array}{l}\text { 赤血球 }(+) \\
\text { 泉血球 }(+) \\
\text { 菌 } \quad(\text { 正 }\end{array}\right.$ & $\begin{array}{l}\text { 両側 } \\
\text { 機能低 } \\
\text { 下 }\end{array}$ & 発赤 & & 抗菌剤 & $\begin{array}{l}\text { 排尿時撮影で V U } \\
\mathrm{R}(+)^{2} \text { 第 } 4 \text { 図 } \\
\text { 第 } 5 \text { 図第 } 6 \text { 図 } \\
\text { 第 } 7 \text { 図 }\end{array}$ \\
\hline 3 & 11 & 男 & \begin{tabular}{|l} 
右蜸 \\
监炎
\end{tabular} & $\begin{array}{l}360 \\
300 \\
250\end{array}$ & $\begin{array}{l}0 \\
0 \\
0\end{array}$ & $\begin{array}{l}\text { 右( I ) } \\
(\text { (一) }\end{array}$ & $\left\{\begin{array}{l}\text { 右(III) } \\
(\text { (一) } \\
(\text { 一 })\end{array}\right.$ & $\left|\begin{array}{c}\text { 右( III) } \\
(\text { - }) \\
(-)\end{array}\right|$ & $\left\{\begin{array}{l}\text { 赤血球 (士) } \\
\text { 自血球(士) } \\
\text { 菌 } \quad(\text { (一) } \\
\text { 正 } \\
\text { 正 }\end{array}\right.$ & $\begin{array}{l}\text { 右側 } \\
\text { 機能低 } \\
\text { 左側 } \\
\text { 正常 }\end{array}$ & 正常 & $\mid$\begin{tabular}{|l|} 
盤張 \\
膀胱 \\
\end{tabular} & $\begin{array}{l}\text { tripple } \\
\text { voiding } \\
\text { 抗菌剤 }\end{array}$ & $\begin{array}{l}\text { 排尿時撮影でVU } \\
\mathrm{R}(- \text { (一) } \\
\text { 第 } 8 \text { 図第 } 9 \text { 図 } \\
\text { 第10図 }\end{array}$ \\
\hline 4 & 7 & 女 & $\begin{array}{l}\text { 右腎 } \\
\text { 結核 }\end{array}$ & $\begin{array}{l}30 \\
30\end{array}$ & $\begin{array}{l}0 \\
0\end{array}$ & $\begin{array}{l}\text { 左 (III) } \\
\text { 左 ( III) }\end{array}$ & $\left\{\begin{array}{c}(-) \\
|c| c \mid\end{array}\right.$ & $($ 左 $($ III $)$ & 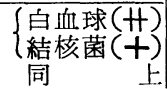 & $\begin{array}{l}\text { 左側正 } \\
\text { 常右側 } \\
(-)\end{array}$ & & & 右腎摘除 & 第11図 \\
\hline 5 & 6 & 男 & 包 茥 & $\begin{array}{l}130 \\
130\end{array}$ & $\begin{array}{l}0 \\
0\end{array}$ & $\begin{array}{l}\text { 右( I ) } \\
(-)\end{array}$ & $\mid \begin{array}{l}\text { 右( I ) } \\
(\text { ( ) }\end{array}$ & $\begin{array}{l}(-) \\
(-)\end{array}$ & $\begin{array}{ll}\text { 正 } & \text { 常 } \\
\text { 正 } & \text { 常 }\end{array}$ & 正 常 & 正常 & 正常 & 形成手術 & $\begin{array}{l}\text { 排尿時撮影でV U } \\
\mathrm{R}(-)\end{array}$ \\
\hline 6 & 10 & 女 & $\begin{array}{l}\text { 急性膀 } \\
\text { 腅炎 }\end{array}$ & $\begin{array}{l}100 \\
150\end{array}$ & $\begin{array}{r}12 \\
0\end{array}$ & $(-)$ & 右(I) & $(-)$ & $\left\{\begin{array}{l}\text { 赤血球 }( \pm) \\
\text { 皇血球 }(+) \\
\text { 正 }\end{array}\right.$ & 正 常 & 正常 & 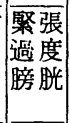 & 抗菌剤 & \\
\hline 7 & 12 & 女 & \begin{tabular}{|l|} 
神経因 \\
性膀脱
\end{tabular} & $\begin{array}{l}80 \\
80\end{array}$ & $\begin{array}{r}25 \\
5\end{array}$ & $\begin{array}{l}\text { 両 (III) } \\
\text { 両 }(\text { III })\end{array}$ & $\left\{\begin{array}{l}\text { 両 (III) } \\
\text { 左 (III) } \\
\text { 石 }(\text { I })\end{array}\right.$ & \begin{tabular}{|l|} 
両 $($ III $)$ \\
両 $($ III $)$ \\
\end{tabular} & $\begin{array}{l}\left\{\begin{array}{l}\text { 赤血球 }(+) \\
\text { 自球 }(+ \text { 古) }\end{array}\right. \\
\left\{\begin{array}{l}\text { 赤血球 }(+) \\
\text { 白血球 }(+)\end{array}\right.\end{array}$ & 水腎症 & 肉柱 & 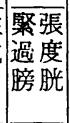 & $\begin{array}{l}\text { 尿道拡張 } \\
\text { 留直カテー } \\
\text { テル }\end{array}$ & $\begin{array}{l}\text { 第13区 } \\
\text { 第14図 } \\
\text { 第15区 } \\
\text { 第16図 }\end{array}$ \\
\hline 8 & 6 & 男 & 包 䔄 & $\begin{array}{l}100 \\
120\end{array}$ & $\begin{array}{r}20 \\
5\end{array}$ & $(-)$ & $(-)$ & \begin{tabular}{|l|} 
両 $($ III $)$ \\
両 $($ III $)$
\end{tabular} & $\begin{array}{ll}\text { 正 } & \text { 常 } \\
\text { 正 } & \text { 常 }\end{array}$ & 正 常 & & & 形成手術 & $\begin{array}{l}\text { 第17図 } \\
\text { 第18図 }\end{array}$ \\
\hline 9 & 9 & 女 & 遗尿症 & $\begin{array}{l}100 \\
150\end{array}$ & $\begin{array}{r}10 \\
0\end{array}$ & 左( I ) & $\left|\frac{\text { 左( I ) }}{(-)}\right|$ & $\mid \begin{array}{l}(-) \\
(-)\end{array}$ & $\begin{array}{l}\text { 正 } \\
\text { 正 }\end{array}$ & 正 常 & 正常 & 正常 & 尿道拡張 & \\
\hline
\end{tabular}

（I ）：第 1 度逆流（II）：第 2 度逆流（II）：第 3 度逆流 
1 例で他は正常所見を示した.

2）膀胱像の洔間的推移について

小児の膀胱像は種々の因子の影響を受け，円形乃至卵 円形を呈するととが稀で, 特に延引性撮影では充満度が 不完全のために不正形を示す場合が多い。この反面，時 間の経過と共に尿が貯溜するため最も生理的な膀胱像の 推移が観察される.

\section{a) 膀胱下縁の位置}

各時間撮影像のそろつている症例中の特殊膀胱疾患安 除く68例の観察で, 膀胱下縁恃時間的推移にかかわらず 恥骨との位置的関係において，全例に変動が見られなか つた.

膀胱下縁と恥骨とが $1 \mathrm{~cm}$ 以上重なるものが 68 例中 14 例 あり，それを性別，年令別にみると第 4 表の如くであ る.5才以下では男児女児共膀胱下縁が恥骨と重なるも のは 11例中 1 例むないが, 10 才以下では 38 例中 7 例 (18.4\%) にみられ，男児の方がその頻度が大きい. 14 才以下になると更にその頻度を增して 27 例中 7 例 $(25.9$ \%)となつている，乙れを疾患別にみると，14例中遺尿 症 8 例 (男児 5 例, 女児 3 例) 亡過半数点占力, 次いで 膀胱炎の 3 例となつている.

第 4 表

\begin{tabular}{|c|c|c|c|c|}
\hline 性: & 5 才以下 & 10 才以下 & 14 寸以下 & 計 \\
\hline 男 & $3(0)$ & $22(6)$ & $10(3)$ & $39(9)$ \\
\hline 女 & $8(0)$ & 13 (1) & $12(4)$ & $33(5)$ \\
\hline 計 & $11(0)$ & $35(7)$ & $22(7)$ & $68(14)$ \\
\hline
\end{tabular}

（）は䧛胱下緑と恥骨とが重つた症例

\section{b) 膀胱像の拡張椂式}

直後撮影で不正形, 半円形を呈する膀胱像は時間的経 過上共に拡大寸るが，その拡張変化は下縁が固定して をり，上縁の垂直方向が最も著明で正中線より左右に向 い放射状に拡がりを示し, 水平方向への拡大は最も少な い. 直後撮影と60分後撮影の膀胱像について最大繸径と 最大横径との拡大度を調べた。但し膀胱疾患で膀胱像に 特別の変化が認められる症例は除外し，71例について観 察した.

\section{1）縦径の拡大度}

60 分後撮影の最大縦径を直後撮影の最大縦径で除して

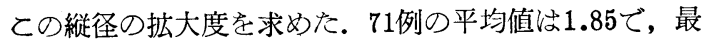
小惐は 1.05 , 最大值は 2.43 であつた。 但し 2.2 以上の高
值を示した 8 例中 6 例は途中強い尿意を訴えた。

口）横径の拡大度

60 分後撮影の最大横径と直後撮影の最大横径とを測定 し，縦径の場合と同様に前者を後者で除して求めた．測 定した71例の平均值は $1.32 て ゙$, 最小値は 1.02 , 最高值註 1.48であつた。

八) 縦径の拡大度と横径の拡大度との比

先に測定した横径, 縦径の60分間の拡大度を比較し, 縦径の拡大度を横径の拡大度で除した值を第 5 表に表示 した. 即与男児, 女児共拡大度で類似した値を示し, 1.2以下は男女児共 1 例であるが， $1.2 \sim 1.5$ の範囲に 属するものは 男児 30 例，女児 29 例 とその過半数 (83.1 $\%$ を占め, 1.5 以上のものは男児 4 例，女児 6 例で， この中約半数の 6 例梳 60 分の経過中治、尿意を訴元 た。この値と疾患との間には特異性は みられなかつた が, 下部尿路正常の13例はいずれも $1.2 \sim 1.5$ の範囲内 にあつた。

第 5 表

\begin{tabular}{|c|c|c|c|}
\hline $\begin{array}{c}\text { 縦径拡大度 } \\
\text { 横径执大度 }\end{array}$ & 男 & 女 & 計 \\
\hline 1.2 以下 & 1 & 1 & 2 \\
\hline $1.2 \sim 1.5$ & 30 & 29 & 59 \\
\hline 1.5 以上 & 4 & 6 & 10 \\
\hline 計 & 35 & 36 & 71 \\
\hline
\end{tabular}

C) 膀胱像の形態的変化

膀胱像が直後, 30 分後打よび60分後に完全に描出され た71例につき観察した.

充満度の不完全な膀胱像恬すべて上縁が平坦又は樎凹! して半円形, 不正形, 逆三角形を呈するが, その殆どは 時間的経過と共に漸次上縁が拡張して卵円形, 円形に近 付く(第24図, 第25図).膀胱症状のない症例ではいずれ も辺縁平滑であるのに反し, 膀腃炎症例では大多数が鋸 蒾状，凸凹の辺縁を呈する．乙の鋸歯状縁は時間的経過 に無関係に各撮影に共通的に観察された。時間的推移に よる膀胱像の形態的变化を示すと第 6 表の如くになる. 逆三角形，不正形，半円形を示した膀胱像の93\%は卵円 形となるが，依然として不正形を示したものも5例含ま れた. この 5 例拄膀胱の器質的疾患 (膀胱憩室, 肉柱膀 胱）乞膀胱像の外に腸内容が充満圧迫している像が観察 された。 


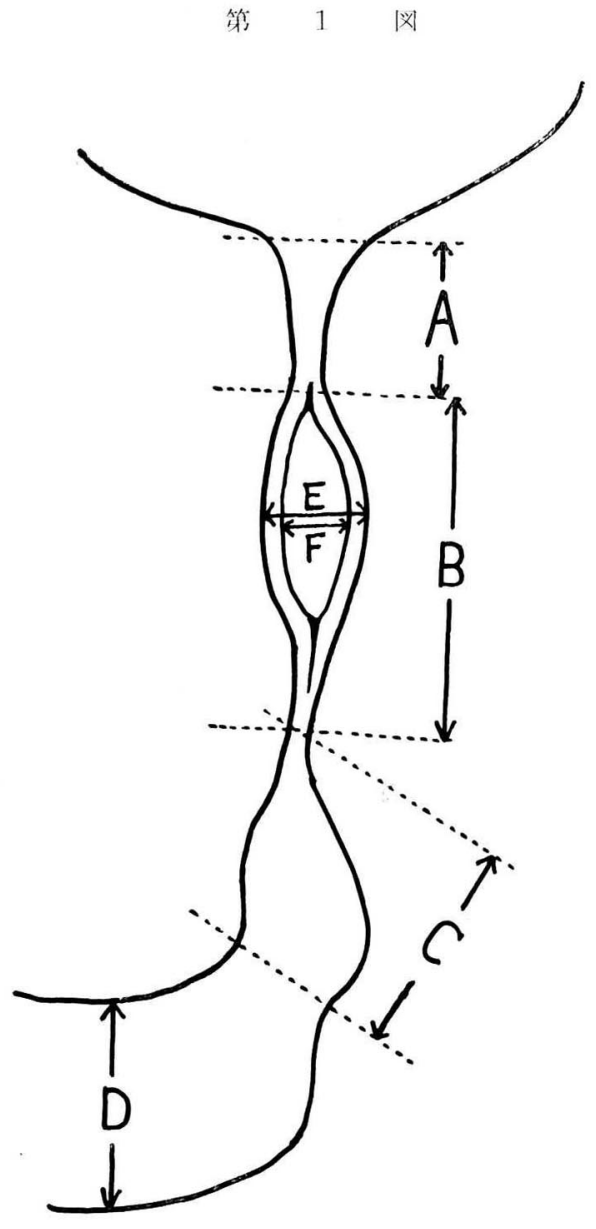

第 2 成

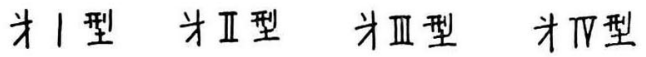

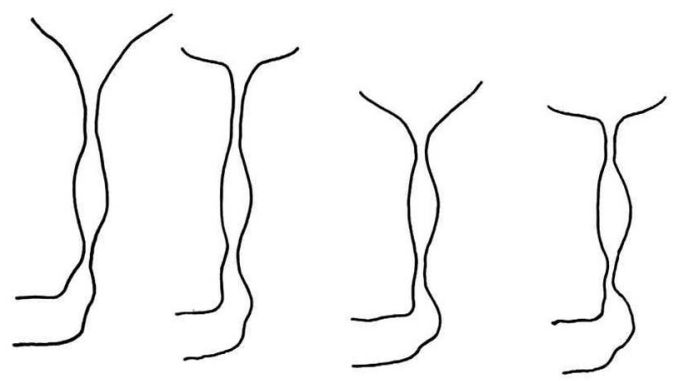

正中線に刘多る左右刘称性在みる上第 7 表の如くであ る. 刘称性圭示与ものが最毛多く59例在占め, 非刘称性 のものが自後撮影では12例 (16\%) あつたが, 時閒的経

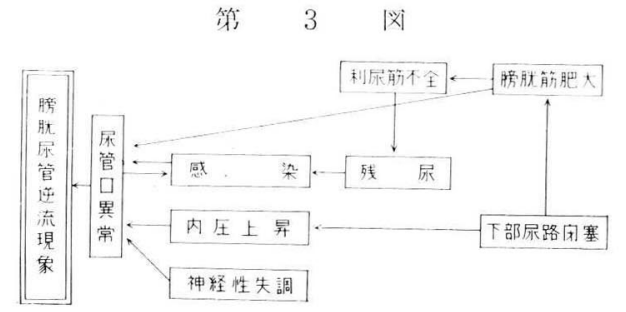

第 4 目 7 才, 男 急性膀胱炎（直後撮影）

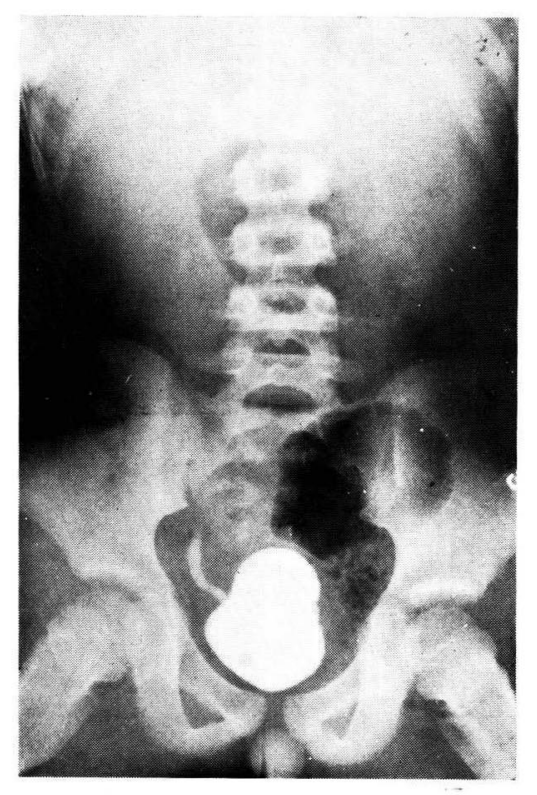

第 5 成同上（排尿蝺撮影）

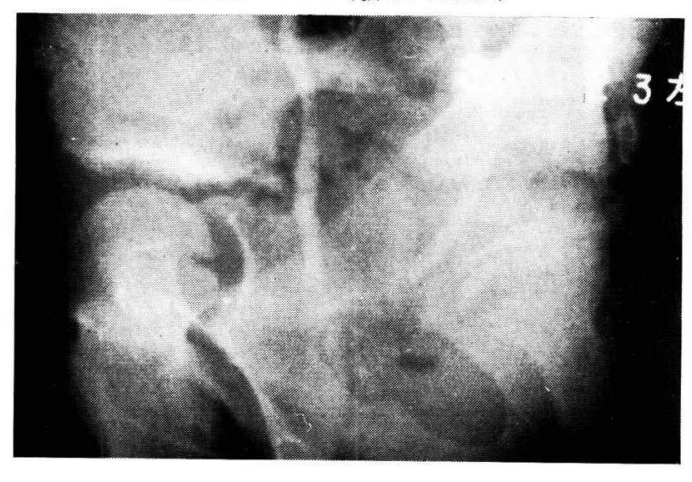

過と共飞その約 $1 / 3$ 好刘称性在小寸に至り, 又約 $1 / 3$

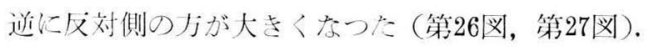

これらの変化についてい性, 年令, 疾患（哭所的疾患 在除く）に上る错異は認められなかつた。 
第 6 図 同前 治療後（直後撮影）

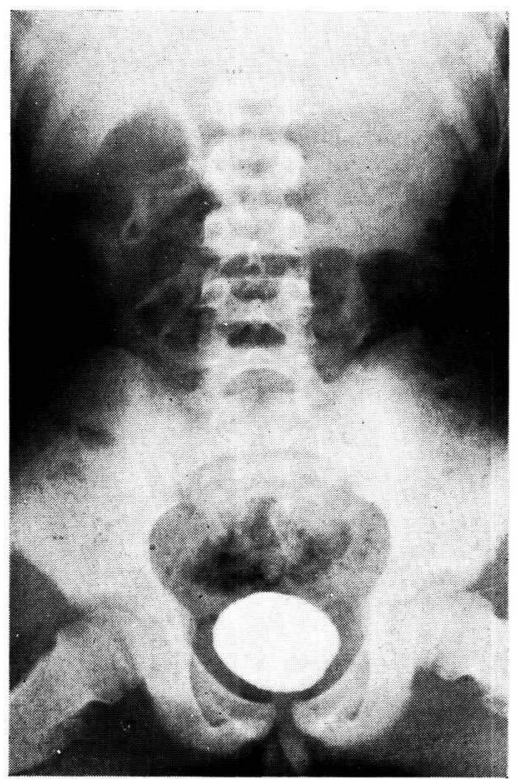

第 7 润 同上 治療後 (30分後撮影)

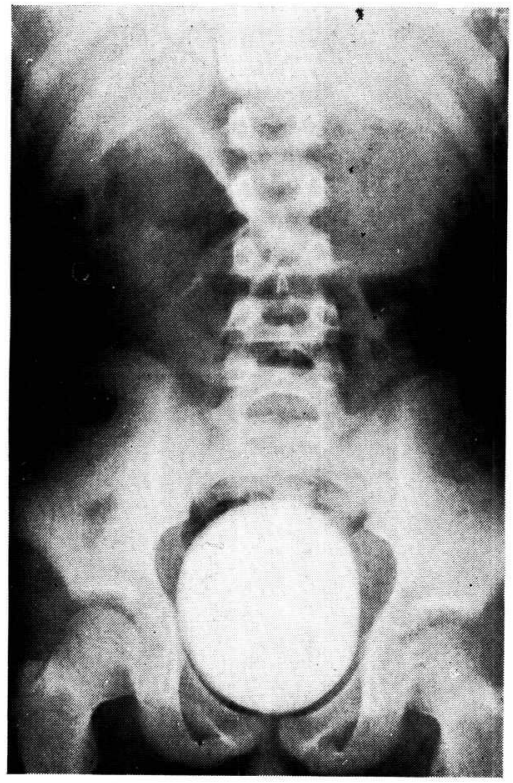

d) 膀胱下縁像

膀胱下縁が完全に描出された75例について検討学加光 た.

膀胱下縁像は膀脱充満度にかかわらず下方に凸面在有 し且つ平滑である。然し遗尿症执よび急性膀脱炎の症例
第 8 阀 11 才, 男 右腎盂炎（直後撮影）

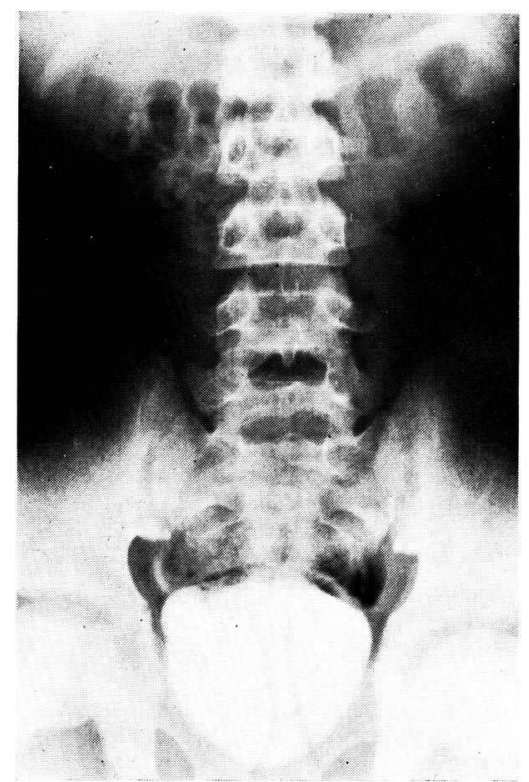

筑 9 闵同上: (60分後撮影)

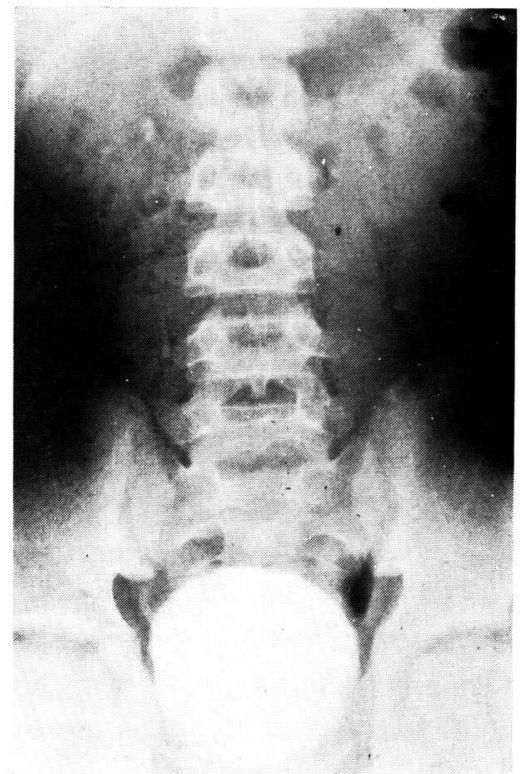

に膀胱頚部の漏斗状突出が衿められるこ上が女る。殊に 遗㲾症の約 $20 \%$ 亿漏斗状突出像老認义, その中の約半数 は直後撮影では平滑な下緑像圭呈していたが，30分後亦 るい㤝60分後撮影で漏斗状突出像の出現在久た。直後, 30 分後, 60 分後撮影心小り膀胱䅡部の漏斗状突出在示し 
第10汹同前（静脈注射腎杰撮影正迫带除去後10分）

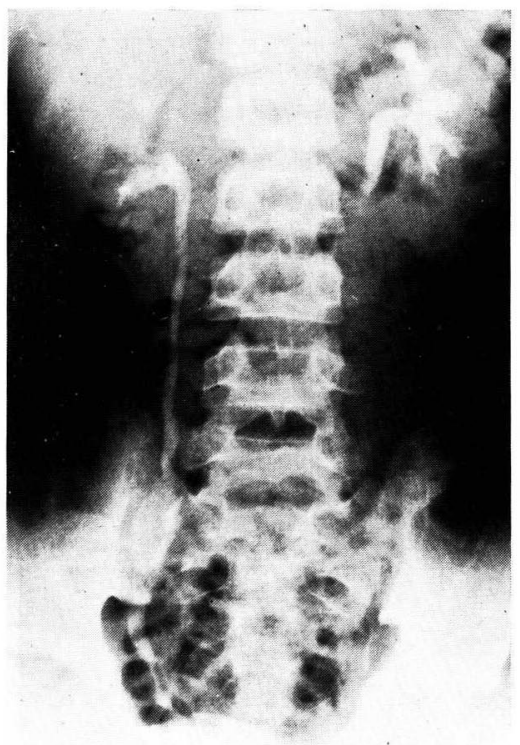

第11戍 7 才，父 有腎絬核（直後撮影）

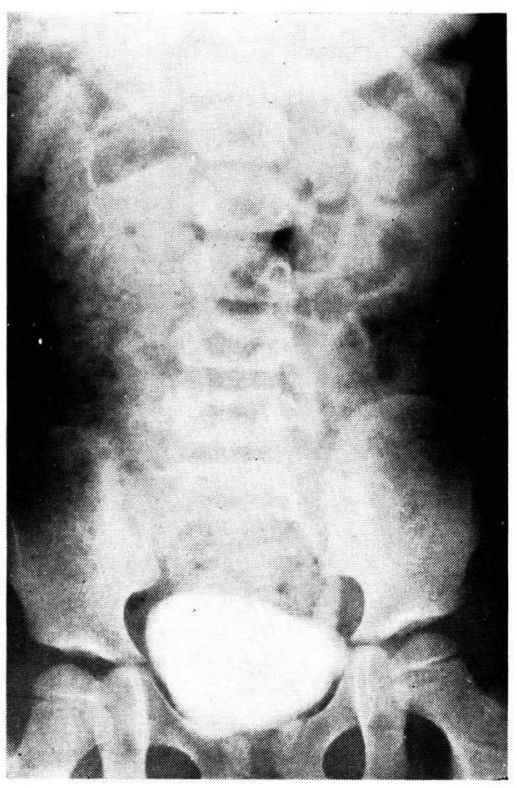

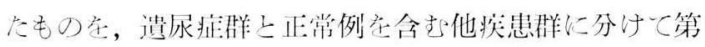
8 表に示子。他垸患群中 4 例の漏斗状突出例心いずれも

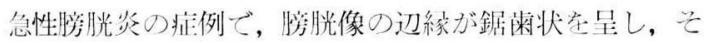

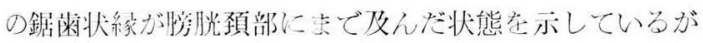

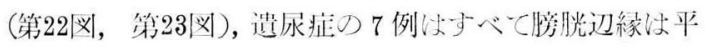

第12戍同前 (30分後撮影)

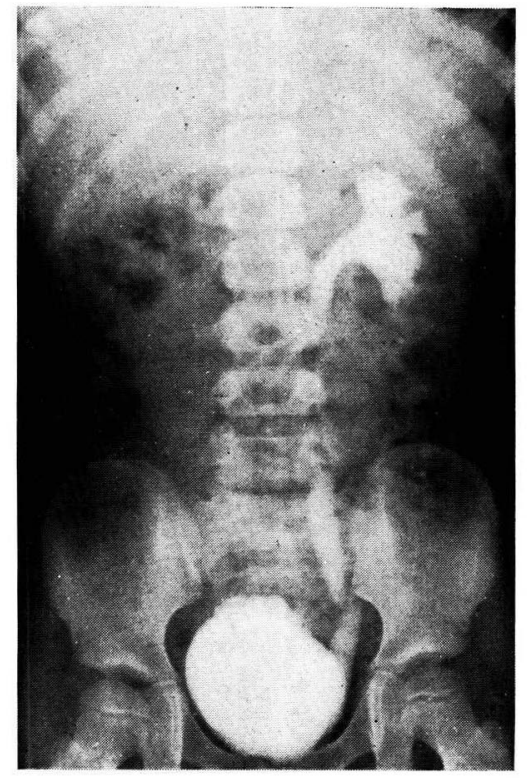

第13汹12才, 女神経因性膀胱治燎後（直後撮影）

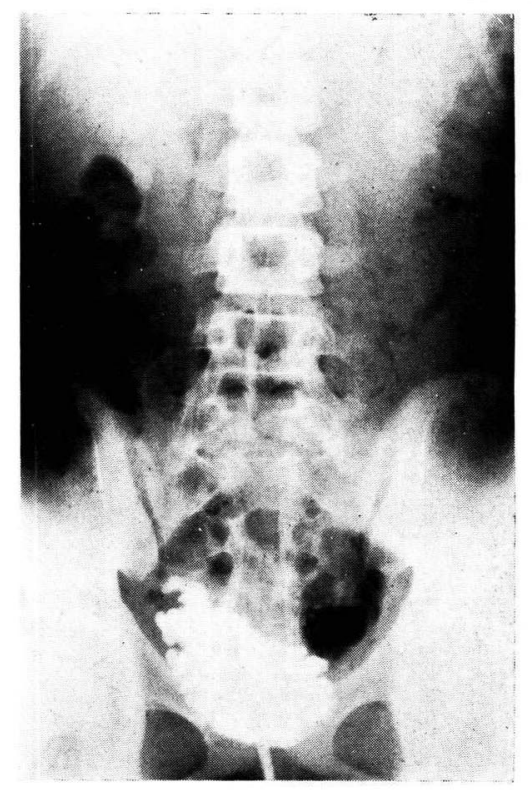

滑で勝胱䅡部にのみ異常容出圭認めた（第19図，第20 四, 第21図). 自覚的に心前者が強い尿意孛訴えたのに反 し, 後者は 60 分間に亘り䏽胱内造影剂保持が可能で尿意 在強く鼎えなかつた。

B ）排尿時尿道膀脱撮影 
第14戍同前（30分後撮影）

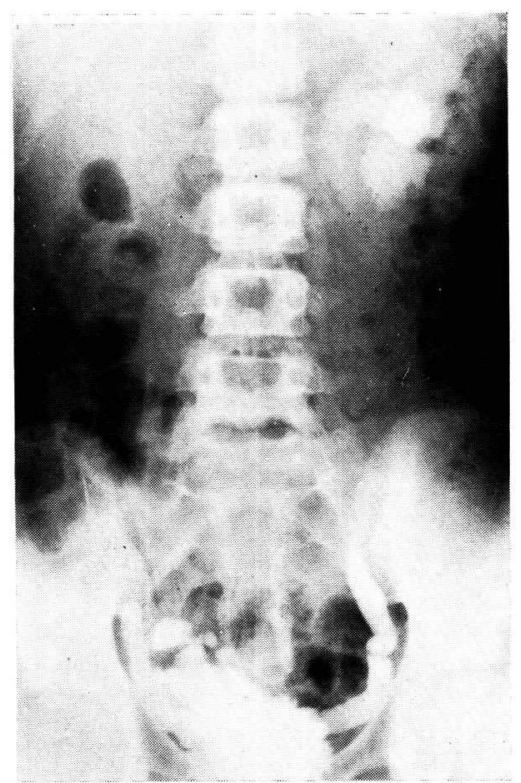

策15図 同上（60分後撮影）

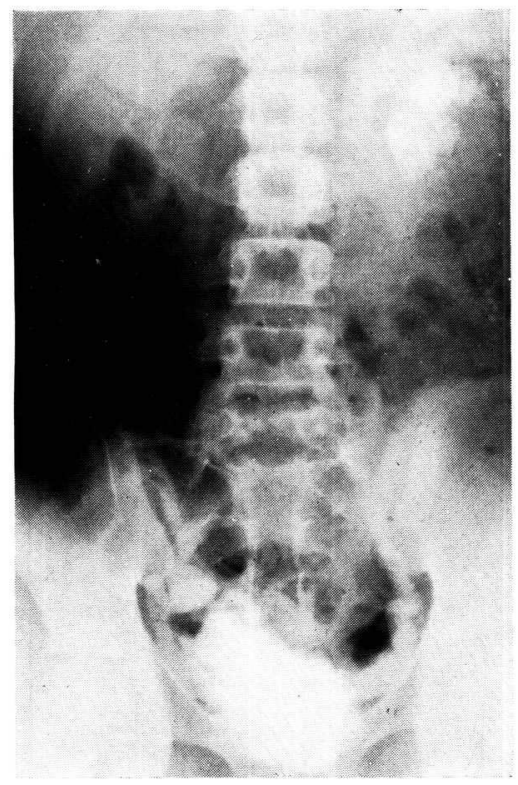

検在刘象は14才以下の思児に限り，19例に丰施した。

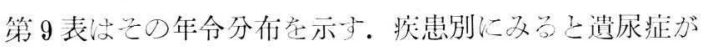
最も多く 11 例, 膀胱炎 4 例, 包苳 2 例沶よび腎盂炎の 1 例となつている。

1) VUR について
第16脳同上（静脈注射腎血撮影）

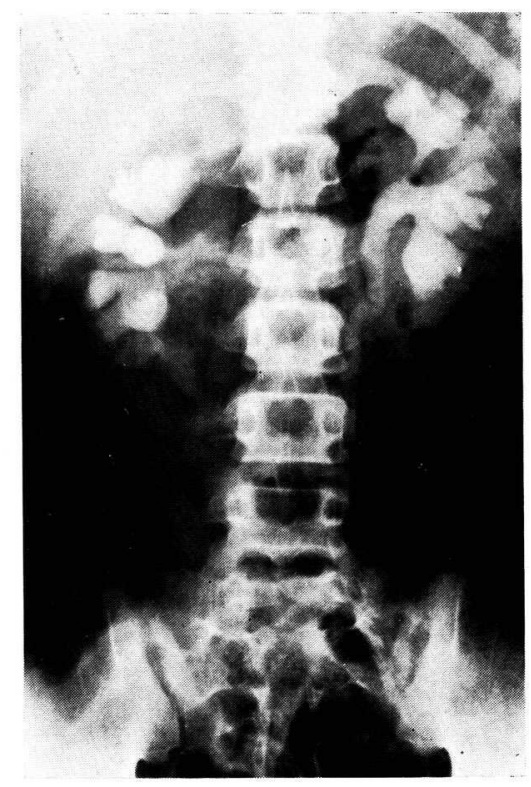

第17汹 6 才，男 真性包茥（直後撮影）

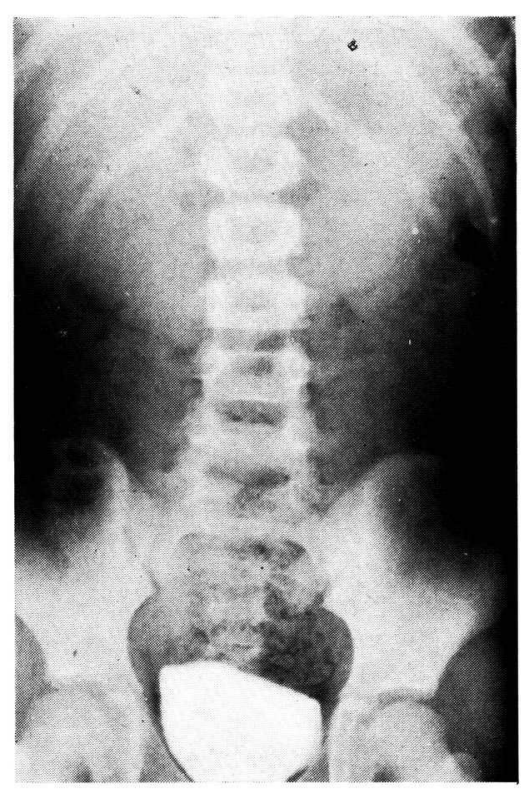

排尿時撮影を行なつた19例中に纺, 延引性撮影でVUR 在認め症例が 4 例, 即与遺尿症, 勝胱炎, 腎孟炎, 包茎の各 1 例が含まれているが, 排尿時撮影て VUR 在

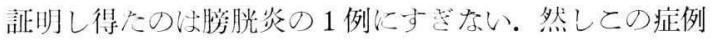
以趾引性撮影では右侧第 1 度逆流圭示したが, 排尿時撮 
第18図同上（60分後撮影）

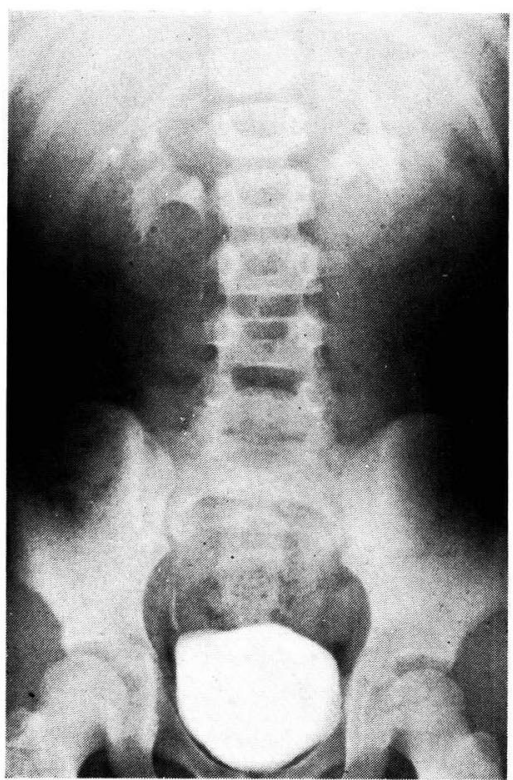

籍19坟12才，男遗㽷症（直後撮影）

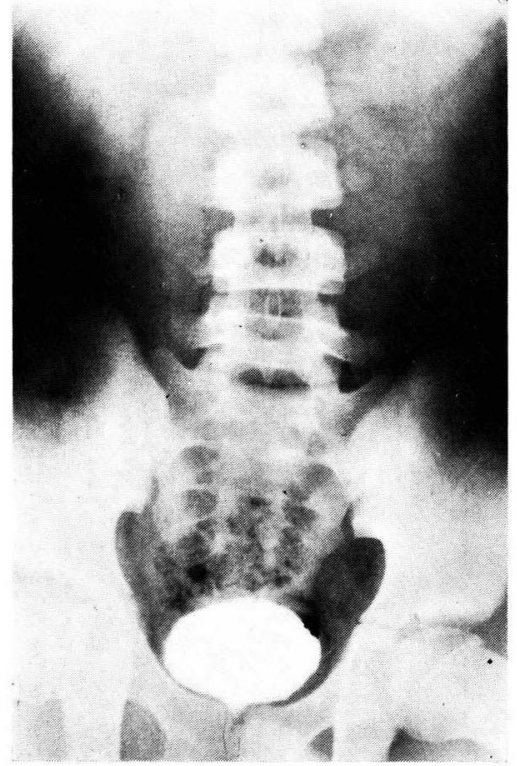

影に执いては両侧第3 度近流とその程度の增强が少られ た(第 5 阆).

2）湾胱䅡部の形態について

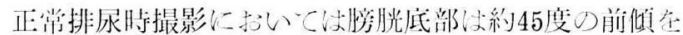

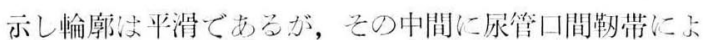

第20成同上（30分後撮影）

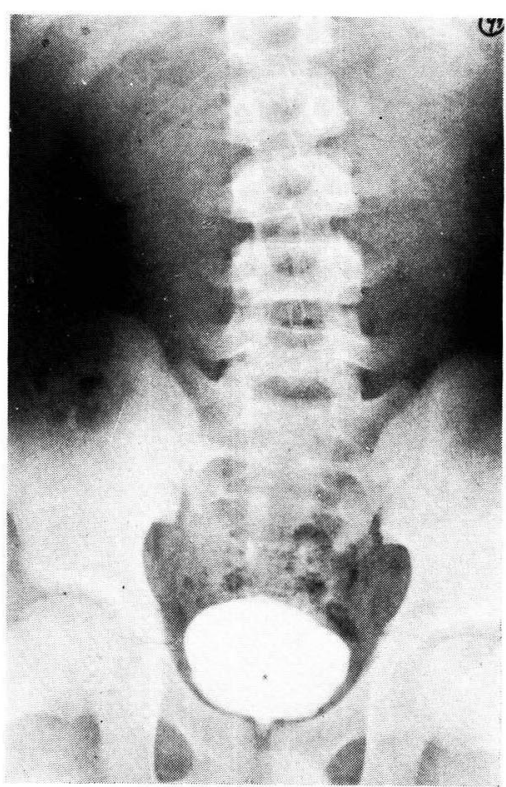

第21为 同上:(60分後撮影)

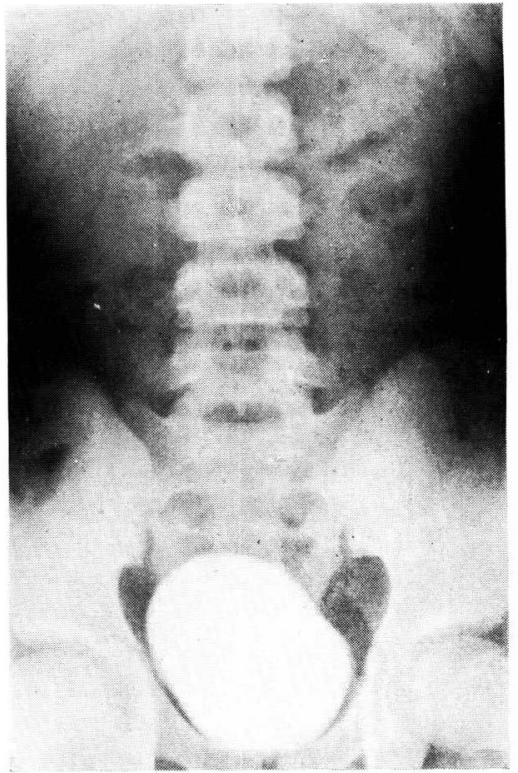

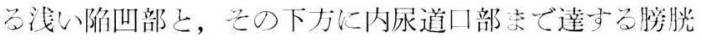
三角部奈示す軽い膨隆がみられる。更に内尿道口部に心 内括約朌に上る絞扼部がみられ，乙の絞扼部から前立腺

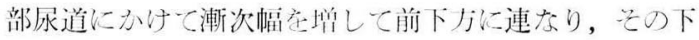
方に M. compressor nudae に上る㥛端な内弯がみられ 
第22図8才，男 急性腤胱炎（直後撮影）

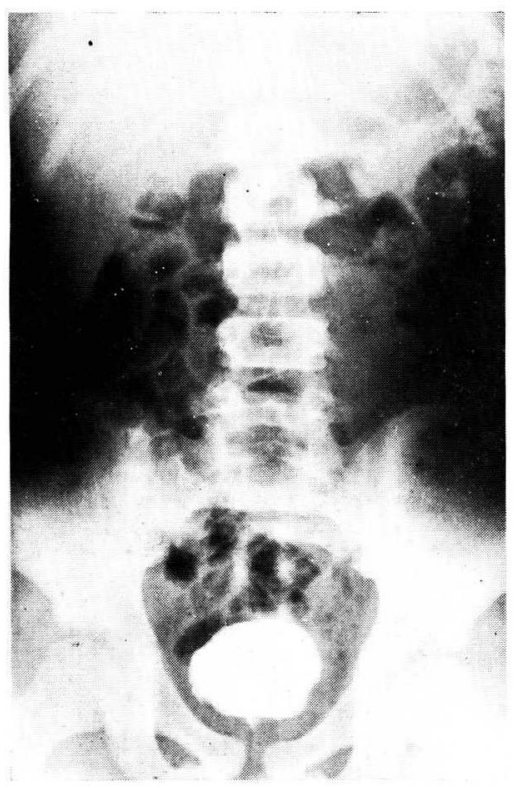

第23圀 同上（60分後撮影）

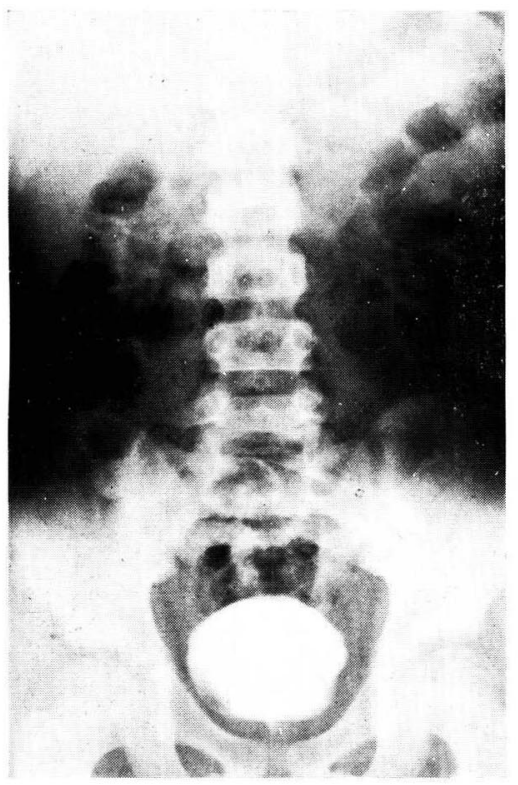

光(第28図).

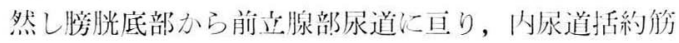
に上る絞扼像在示さず，広い膀胱頚部像在虽するもの が, 19 症例中, 遗尿症: 2 例, 息性膀胱炎 1 例つ 3 例に観 察された。この3 例は共に延引性撮影で脖胱頚部の漏斗
第21四 3 才，男尿道下裂（直後撮影）

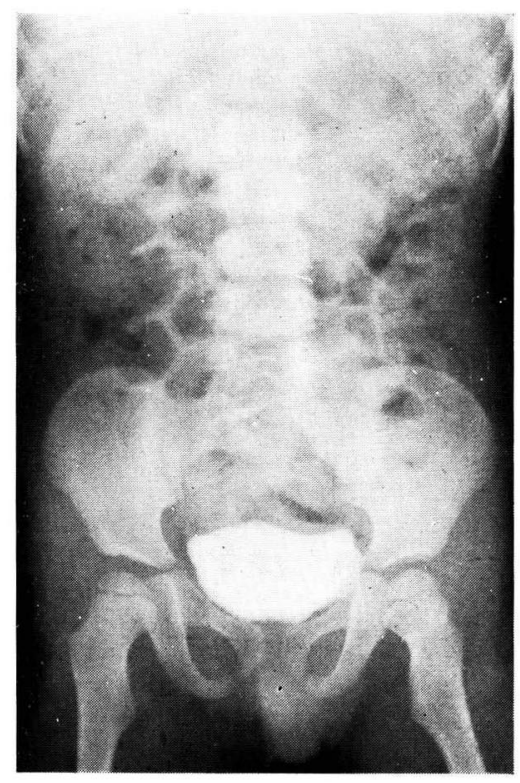

符25脑间上: (60分後撮影)

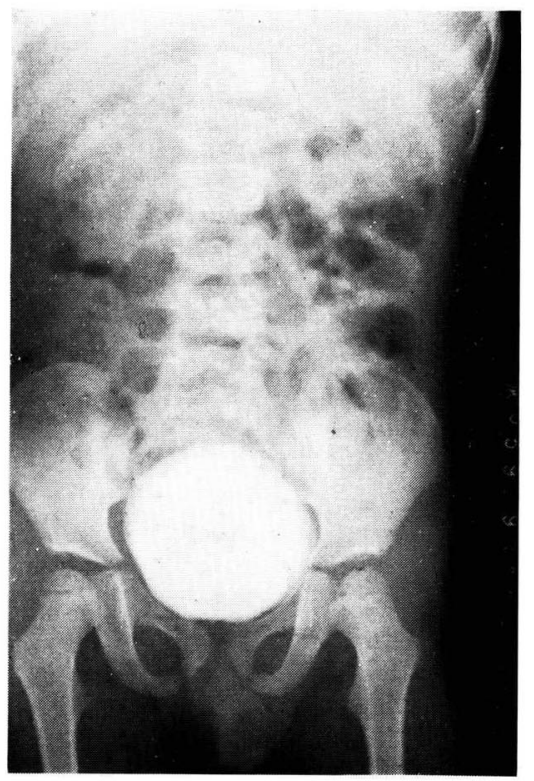

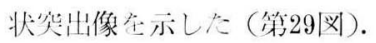

C) 近行性㽷道膀胱提影

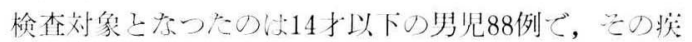

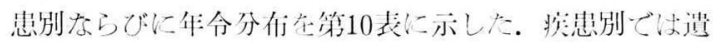
㽷症が压倒的に多く50例全数える。㽷道疾患11例中にな 
管26济11才，男 泌尿器科的正常例（直後撮影）

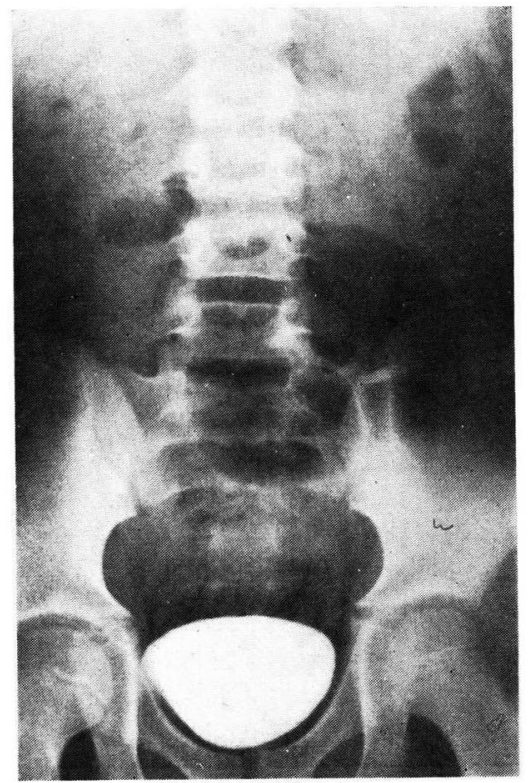

第27浽间上（60分後撮影）

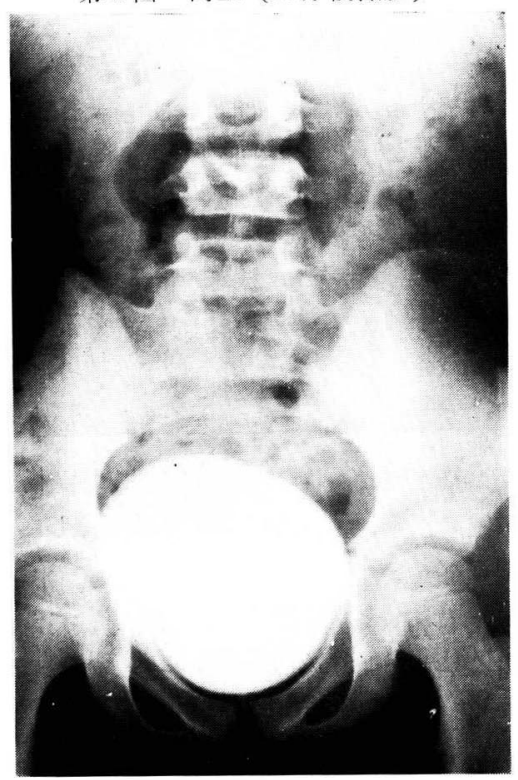

外榎性:尿道狄空 5 例，尿道炎 4 例，尿逆異物 1 例。結榜

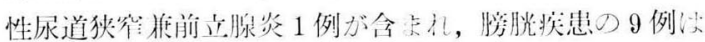

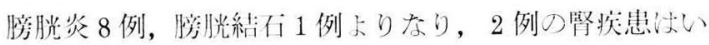
ずれも腎㙉炎である。尿道狄寉では狄寉部が朋膫に描: され，前立腺炎では前立腺への造影剂つ侵入像无得られ，

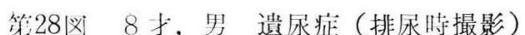

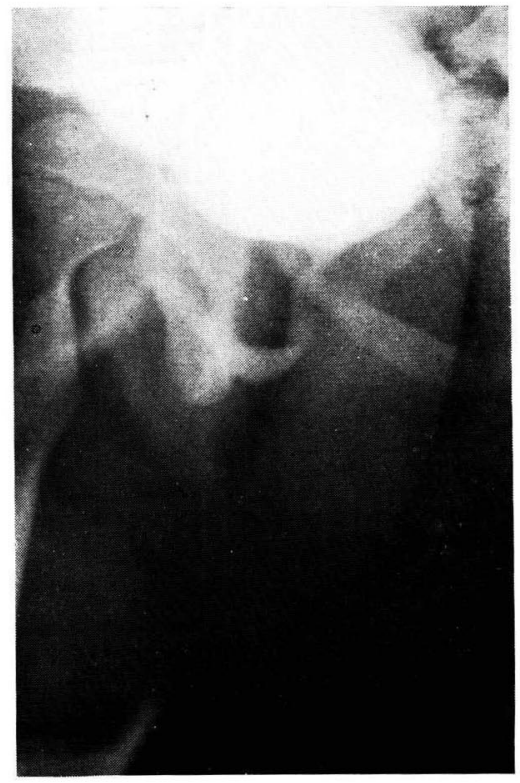

第29図14才，男遗尿症（排尿時撮影）

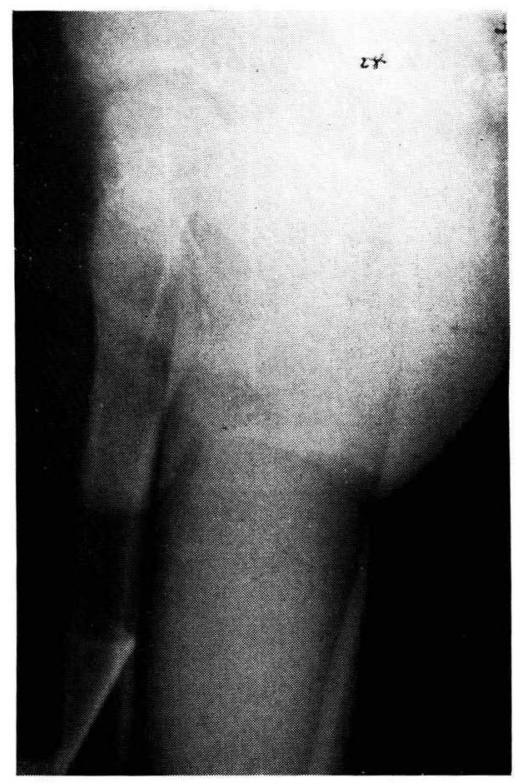

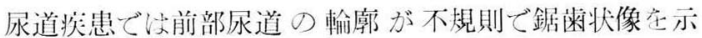
し，いずれも成人に护名疾患のレ線像上同様である (第34図, 第35図).

1）尿道の計測について

提影時の操作に上り影響老受け易い尿道振了部在除 
第30図14才，男 遗尿㑊（注: 入洔尿道膀胱撮影）

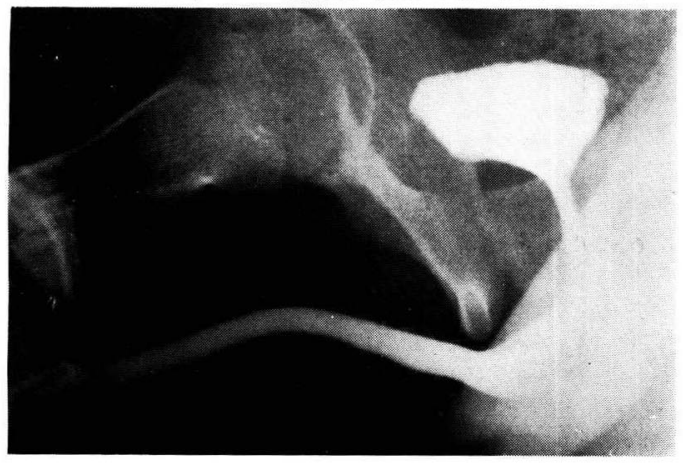

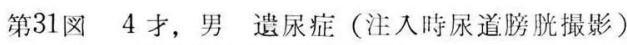

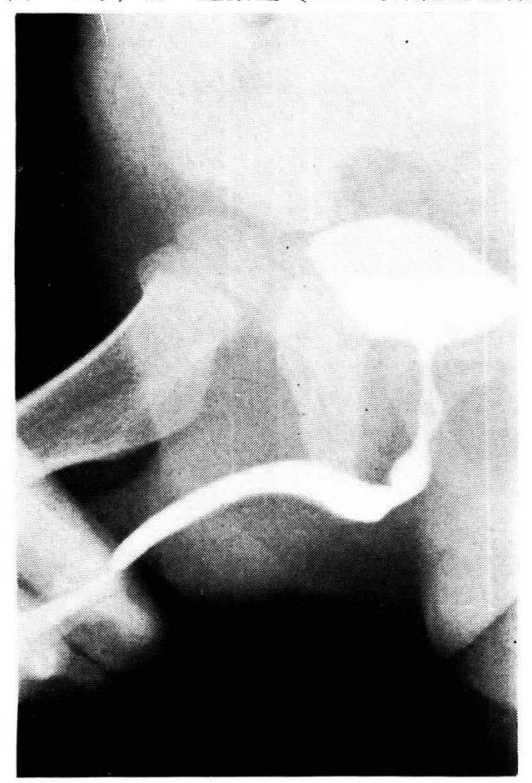

第32図 10 才, 罗 遗尿症（注入時尿道膀脱撮影）

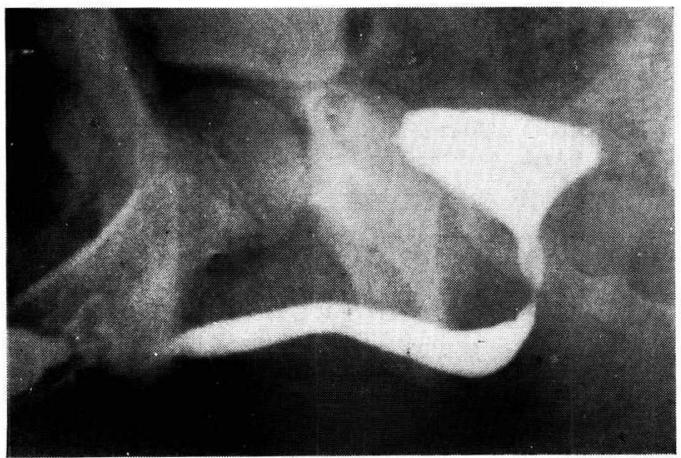

き, 男先尿道老次の各部に分け，正常像在呈した症例 ほつき，レントゲンフィルム上で計測した．各点の選定

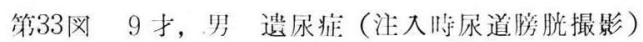

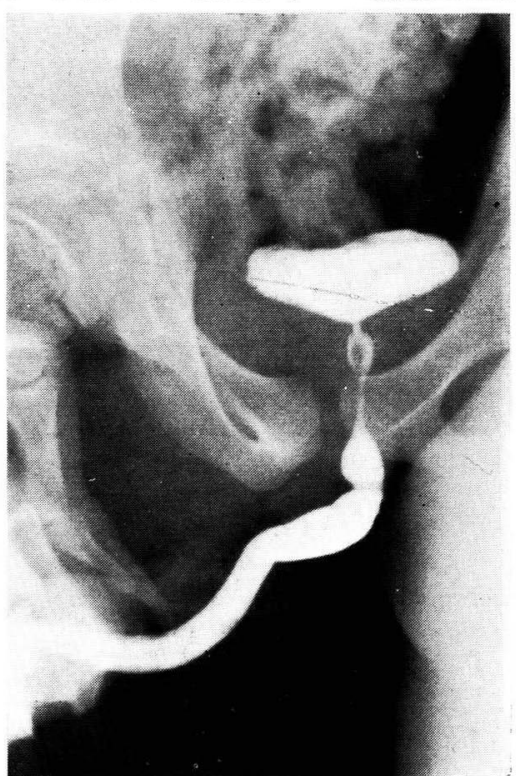

第34四14才，男遗尿老主訴とした尿道狭窄兼

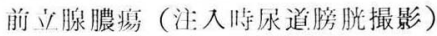

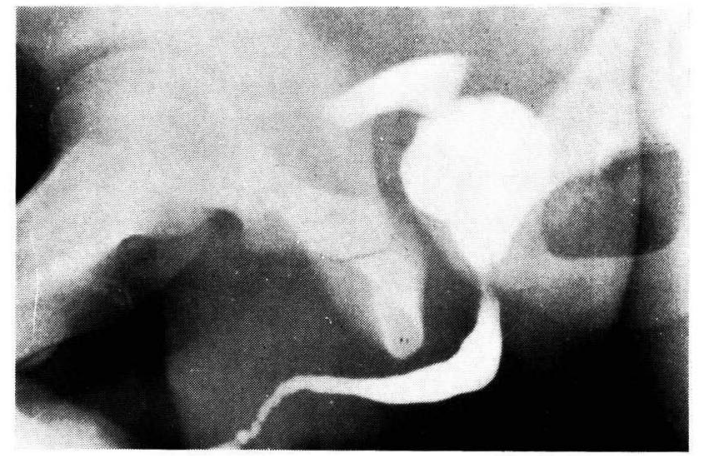

に汸鮮明に描出された症例のみ集め, 注入時撮影, 冝 盤底筋收縮時撮影，注入後撮影圭比較対照して沈定した (第 1 図).
$\Lambda$ ：内尿道口部々精丘直上部
$\mathrm{B}$ ：精丘自上部上外括約等部最狄部
C：外括約等部最㹨部上 M. compressor nudae の腱 性附管部

$\mathrm{D}$ ：球部尿部の最広部の横径

$\mathrm{E} ：$ 前立腺部尿道の最应部の横径

$\mathrm{F}$ : 精质の横堡

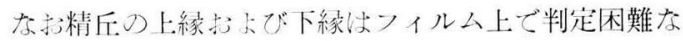
症例が多くそのために精丘の長さの計測は出来なかつ i. 
第35四 10 f, 男急性膀腅炎（注入時尿道膀胱撮影）

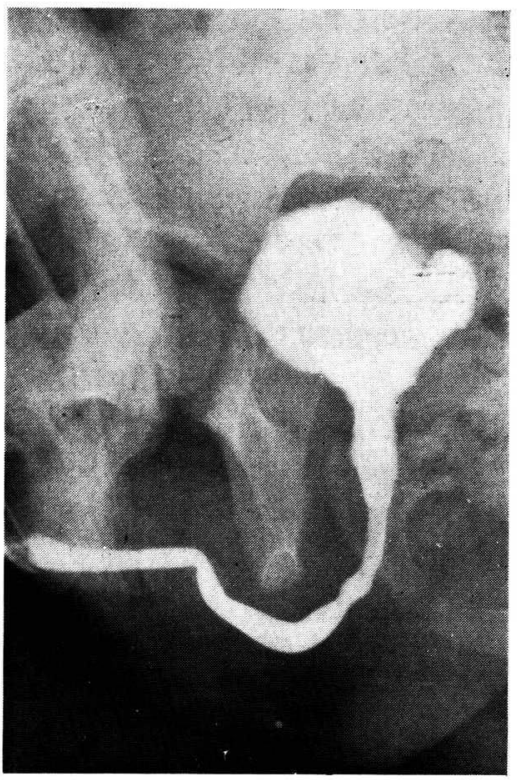

第 6 表

\begin{tabular}{|c|c|c|c|}
\hline 60 分後 & 罗 & 女 & 計 \\
\hline 逆三们形，卵円形 & 1 & 1 & 2 \\
\hline 不 正 形 $\rightarrow$ 卵円形 & 5 & 3 & 8 \\
\hline 半 户 形，卵円形 & 29 & 27 & 56 \\
\hline 不正形 $\rightarrow$ 不归形 & 0 & 5 & 5 \\
\hline 計 & 35 & 36 & 71 \\
\hline
\end{tabular}

第 7 表

\begin{tabular}{|c|c|c|c|}
\hline 直後 & 60 分後 & 例 & 数 \\
\hline \multicolumn{2}{|c|}{ 右 $=$ 左一一一 } & 5 & \\
\hline \multicolumn{2}{|c|}{ 有>质一一 - $\rightarrow$} & 4 & \\
\hline \multicolumn{2}{|c|}{ 右<左:-一二 $\rightarrow$} & 1 & \\
\hline \multicolumn{2}{|c|}{ 在>有 $\rightarrow$ 位 $=$ 左 } & 2 & \\
\hline \multicolumn{2}{|c|}{ 不>左 $\rightarrow$ 有 $<$ 左 } & 1 & \\
\hline \multicolumn{2}{|c|}{ 右<左: $\rightarrow$ 右 $=$ 左 } & 2 & \\
\hline \multicolumn{2}{|c|}{ 有 $<$ 㢈 $\rightarrow$ 不 $>$ 布: } & 2 & \\
\hline
\end{tabular}

第 8 表

\begin{tabular}{|c|c|c|c|}
\hline & & 例数 & $\begin{array}{l}\text { 淉斗状突出像を } \\
\text { 示した例数 }\end{array}$ \\
\hline \multirow{2}{*}{ 遗瓜痉 } & 罗 & $\begin{array}{l}21 \\
13\end{array}$ & $\begin{array}{l}5 \\
2\end{array}$ \\
\hline & 計 & 34 & 7 \\
\hline \multirow{2}{*}{ 他疮思群 } & $\begin{array}{l}\text { 罗 } \\
\text { 女到 }\end{array}$ & $\begin{array}{l}19 \\
22\end{array}$ & $\begin{array}{l}2 \\
2\end{array}$ \\
\hline & 計 & 41 & 4 \\
\hline
\end{tabular}

第 9 表

\begin{tabular}{|l|lllllllll|l}
\hline 年令 & 3 & 7 & 8 & 9 & 10 & 11 & 12 & 13 & 14 & 計 \\
\hline 例数 & 1 & 3 & 3 & 1 & 3 & 3 & 3 & 1 & 1 & 19 \\
\hline
\end{tabular}

第10表

\begin{tabular}{|c|c|c|c|c|c|c|}
\hline 年 合 & 遗尿痤 & 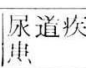 & $\begin{array}{l}\text { 偐胱聅 } \\
\text { 贵 }\end{array}$ & 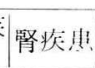 & 正常例 & 計 \\
\hline 1 & & & & & 1 & 1 \\
\hline 2 & & & & & 1 & i \\
\hline 3 & 1 & & & & 2 & 3 \\
\hline 4 & 2 & & & & & 2 \\
\hline 5 & 2 & 2 & & & 1 & 5 \\
\hline 6 & 6 & 1 & 2 & & 2 & 11 \\
\hline 7 & 5 & 1 & 2 & & 1 & 9 \\
\hline 8 & 3 & 1 & & & 3 & 7 \\
\hline 9 & 2 & & & & & 2 \\
\hline 10 & 9 & 1 & 2 & & 3 & 15 \\
\hline 11 & 7 & 2 & 2 & 1 & & 12 \\
\hline 12 & 3 & 1 & & & 2 & 6 \\
\hline 13 & 4 & & & & & 4 \\
\hline 14 & 6 & 2 & 1 & 1 & & 10 \\
\hline 計 & 50 & 11 & 9 & 2 & 11 & 88 \\
\hline
\end{tabular}

第11表

\begin{tabular}{|c|c|c|c|c|c|}
\hline & 例 数 & $\underset{(\mathrm{mm})}{\mathrm{A}} \mid \begin{array}{l}(\mathrm{mm}) \\
{ }_{(\mathrm{mm})}\end{array}$ & $\left|\begin{array}{l}D \\
(\mathrm{~mm})\end{array}\right|$ & $\begin{array}{l}\mathrm{E} \\
(\mathrm{mm})\end{array}$ & F \\
\hline 4 〜 10 才 & 39 & 5.816 .38 .5 & 9.3 & 5.0 & 2.7 \\
\hline 11〜14 寸 & 24 & 6.020 .311 .4 & 11.9 & 5.4 & 2.9 \\
\hline 類宦官症 & 9 & 6.022 .112 .0 & 12.1 & 6.0 & 3.1 \\
\hline & 100 & \begin{tabular}{ll|ll}
6 & 0 & 32.0 & 13.1
\end{tabular} & $\mid 16.4$ & 7.3 & 4. \\
\hline
\end{tabular}

これを 4 才から10才までの39例，11才から14才までの 24 例の 2 群纪分け, 更に小児㲾道と比較する意味で成人 の正常尿道々類宦官症患者の尿道々を計測し，それ等各 群の平均值第11表行した.

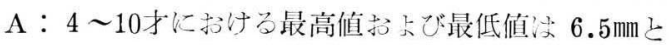
$4.5 \mathrm{~mm}, 11 \sim 14$ 才では $8.0 \mathrm{~mm}$ 乞 $5.5 \mathrm{~mm}$.

B : 4 〜 10才の最高值と最低值决 $18.0 \mathrm{~mm}\llcorner 11.0 \mathrm{~mm}, 11$ 〜 14才では $28.0 \mathrm{~mm}$ と $14.0 \mathrm{~mm}$.

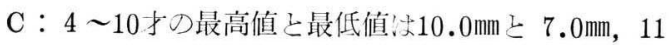
〜14才では $17.0 \mathrm{~mm}$ 上 $7.0 \mathrm{~mm}$.

D : 4 10才の最高值と最低佰は $12.5 \mathrm{~mm}$ 上 $7.0 \mathrm{~mm}, 11$ 〜14オでは $15.0 \mathrm{~mm}$ と $10.0 \mathrm{~mm}$.

$\mathrm{E} ： 4 \sim 10$ 才の最高值と最低值况 $5.5 \mathrm{~mm}$ 己 $4.0 \mathrm{~mm}, 11$ 〜14才でね $6.5 \mathrm{~mm}$ 上 $4.0 \mathrm{~mm}$.

F : 4 10才の最高值と最低值仗 $3.0 \mathrm{~mm}$ 己 $2.5 \mathrm{~mm}, 11$ 
〜14才では $3.5 \mathrm{~mm}$ と $2.5 \mathrm{~mm}$.

総合的にみて, 僅かの例外を認めたが, 大体作令に平 行して後部尿道の長さの変化が観察され, 又同一年令で む体格の相違により各症例に差が認められた。

2）膀胱䪹部の形態について

膀胱碩部の定義に関しては未だ統一を欠いているが, 私怡黒田 ${ }^{622}$ の定義に従つた。精丘部以下の末梢部はすべ て類似の形態を示したのでとの部分を省略し，主として 精丘上部ょり内尿道口部にかけての形態についこ観祭し た.

この項では尿道疾患を除く70例を対象とし，精丘上部 の長さ掞よび内尿道口部の拡張により次の如き 4 型に分 類した。 なお，てれらの症例はいずれも輪廓明膫, 辺䋑 平滑で，局所的充盈欠損亦るい法辺縁不規則像花認めな かつた.

第 I 型：精丘部から内尿道口部までの距離が長く,し かも内尿道口部が著しく拡張して尿道上膀胱底部上が列 んど角度を示さないもの (第30図).

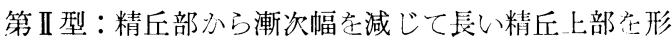
成し, 内尿道口部の拡張老伴わず角度在もつて膛脱底部 に移行するもの(第31図).

第正型：精丘部から内尿道口部紊でが短くし示も内尿 道口部が拡張して膀胱底部との角度を示さないもの（第 32 図).

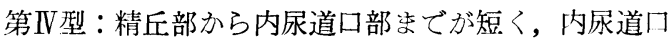
部が拡張していないもの (第33図).

この分類を模型で示すと第 2 圀の如くである.

便宜上, 全症例を遺尿症群扮よび非遺尿症群の 2 群に 分汀，乙の分類に従つて表示した (第12表).乙れを各疾 患別に及ると，第 I 型に注遺尿症 7 例, 急迫尿失禁 1 例 の 8 例が含まれ, 第 II 型が最も多く, 遺尿症 27 例, 正常 例 11 例, 膀胱疾患3例, 腎疾患 1 例の 47 例で, 第 III 型は遺尿 症のみ 11 例, 第 $\mathrm{IV}$ 型以遺尿症 3 例, 膀胱炎 1 例の 4 例である.

第 12 表

\begin{tabular}{|c|c|c|c|}
\hline & 遗尿症群 & 非遺尿症群 & 計 \\
\hline 第 I 型 & 7 & 1 & 8 \\
\hline 第 II 型 & 27 & 20 & 47 \\
\hline 第 III 型 & 11 & 0 & 11 \\
\hline 第IV 型 & 3 & 1 & 4 \\
\hline 計 & 48 & 22 & 70 \\
\hline
\end{tabular}

即与第II 型が最も多く過半数圭占め, 次いで第型, 第 I 型の順となり，第 $\mathrm{V}$ 型は僅か 4 例にすぎない. 更に これを遺尿症群と非遺尿症群に分けてみると興味ある結 果が得られた。即ち両群共に第 II 型 が 最多数空占める
が，特に非遺尿症群でね22例中 20 例とその殆どのものが この型に属し，しかも第 I 型の 1 例岻念迫尿失焚という 遗尿症類似の疾患であるととを思えば，例外は第III 型の 膀腅炎の 1 例のみとなり，第 II 型が非遺尿症群化扗ける 最も舀遍的な型ということが出来る。一方遗尿症群では 48 例中 27 例已半数強老占めた第 II 型と共化, 第 I 型, 第 III 型という遗尿症にのみ久ら机る独特の型が夫及 8 例（前 述の急迫尿失禁老含む), 11例と可成りの数に存在した。 第 $\mathrm{IV}$ 型は 3 例と遺尿症群比比較的多いが，百分率小り及

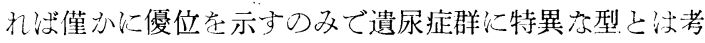
允られない，な打年令と各型との間に恃別な関係流 出し得なかつた。

\section{V. 考 按}

A) 撮影術式について

1）延引性膀胱撮影

私の方法泣 Stewart ${ }^{922}$ によつて創始され, Bunge ${ }^{778)}$ などによつて行なわれている変法に準じて行なつ规が, Dean et al. ${ }^{17)}$ '

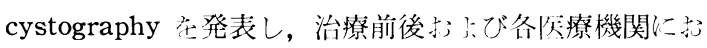

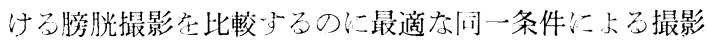

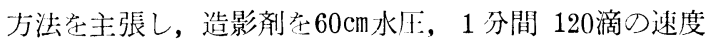
で注入する特殊な注入器を使用した gravity cystography 居行ない, 以後, Spence ${ }^{94)}$, Martin et al. ${ }^{78)}$, Christensen ${ }^{16)}$, Bors \& Comarr $^{5)}$ などはこの方法に依つて いる. Dean et al. ${ }^{177}$, Christensen ${ }^{16)}$ 仿 $60 \mathrm{~cm}$ 水圧が利尿 筋の压力と一致するとして推奖している. 又 Bors \& Comarr ${ }^{5)}$, Pasquier et al. ${ }^{82}$ は膀胱撮影々膀胱内圧測 定を同時に行ないうる装置を考案して両者の間の意味づ けを行なつている.

造影剂注入量に関しては, Stewart ${ }^{92)}$ が被検者の年 令, 協力能力, 膀胱の過敏性を考艒して膀胱に不快感を 感じない程度が最も適当であるとし，又乳児扮よび神経 質な小児に注尿道へのカテーテル插入に伴引压迫感け造 影剂による化学的刺战安なくするために，广め尿道麻醉 在施吉乙と推奖している. Forsythe et al. ${ }^{24)}$, Christensen $^{16)}$ は動物実験で少量の液体在膀脱内一注入与る とVUR先生ずるが，大量の液体注入で以をれ在起さ好 と述べている。私は幼巟には了ぬ尿道粘膜麻酔を施し, 注入量は種々検討の結果, 膀胱容量の $1 / 3$ に規定して撮 影した。

造影剂以その検查目的より当然水溶性で粘稠性の少な い, しかも造影能の大きいものが選ばれ, Frain-Bell et al. ${ }^{25)}$, Christensen ${ }^{16)}$, Stewart ${ }^{92)}$ は刺战の強い造影剂は, 
それ自体 VUR を惹起するとして局所刺㦸のない造影剤 を鹿めている. Martin et al. ${ }^{78)}$ は $5 \% \mathrm{NaJ}$ 溶液では局 所刺战を示さないが, VUR の描出には充分の濃度では ないと述へてている. 私㹥黒化度, 粘稠性, 局所刺战性の 各点より水溶性造影剤である33\% Sugiuron 又は 2 倍稀 釈 Sugiuronを使用し充分の効果を得た。

注入速度に関しては, Stewart ${ }^{92)}$, Bunge ${ }^{7) 8)}$ 法出来る だげ徐々に注入した方が望ましいとし，Dean et al. ${ }^{17)}$, Spence ${ }^{94)}$, Martin et al. ${ }^{78}$ 怄 1 分間 120 滴が最良の条 件としているが, Christensen ${ }^{16)}$ は 1 分間 250 滴が一層 優れているとしている.

撮影体位は, Forsythe \& Wealan ${ }^{24)}$ は斜位45度で, Guiley \& Best ${ }^{31}$ は Trendelenberg 体位で行なつた方 が VURの発現率が大きいと述べているが, Campbell1 ${ }^{121}$ はどんな体位でも発現率は同じであるとしている. Boyce et $\mathrm{al} . .^{6}$, 後藤 ${ }^{30)}$ は VUR が骨陰影掞よび膀胱像に邪 魔されないように蹲位撮影を推奨しているが，性腺保護 の困難性と影像の不鮮明なととにより私は背位撮影で行. なつた。

性腺保護に関し, Forsythe \& Wealan ${ }^{24)}$, Christen$\operatorname{sen}^{16)}$ 㤌厚さ $5 \mathrm{~mm}$ の鉛板で男児の陰囊部を遮蔽している が, 私も被曝量測定の結果厚さ $1 \mathrm{~mm}$ の鉛板を使用した.

2）排尿時尿道膀胱撮影

Stewart ${ }^{92)}$, Kjellberg et al. ${ }^{64)}$ 快特殊な装置で排尿時 撮影を行なつているが，ての方法は実施が非常に困難て あると共に $3 \sim 4$ 才以下の小児では不能である. Stew$: \operatorname{art}^{922}$ 怗非協力的な幼児の場合には膀胱を過度に充満さ せ，カテーテルを报去した後，膀胱部を圧迫して撮影し ている. Forsythe \& Wealan ${ }^{24)}$ は全例を 45 度斜傾位で 撮影しているが，私は原則として立位 45 度斜方向撮影を 行ない, 幼児には充満膀胱の膀胱部圧迫により撮影した. 然し排尿時撮影は神経質な小児には実施が 困難であつ t.

\section{3）逆行性尿道膀胱撮影}

尿道膀胱撮影には排尿時撮影, 注入時撮影, 骨盤底筋 收縮時撮影，注入後撮影があり，更に撮影時の体位には 一背位, 斜位, 側位の各種があり, 斜位には撮影台となす 角度により 30 度，45度，60度などが区別される.

小児尿道撮影に関しては外国では殆ど排尿時尿道膀胱 撮影のみを採用し，膀胱掞よび尿道の機能的検索は勿 論, 形態的変化, 特に尿道狭窄, 膀胱頚部閉塞, 尿道ポ リープ, 神経因性膀胱, 尿道弁膜形成, 精丘肥大症など もこれにより研究されている (Campbell ${ }^{11}$, Edling ${ }^{18)}$,
Fischer \& Forsythe ${ }^{22)}$, Forshall \& Rickmann ${ }^{21)}$, Muellner \& Fleischner ${ }^{42}$ ). 然しこの方法は機能的検査法己 しては優れているが,尿道各部影像の不鮮明なとと,実施 の困難なことなどょり注入時尿道撮影を行なつている者 も少数見られる (Brodny \& Robins ${ }^{3 / 4)}$, Hackworth ${ }^{43)}$ ). 本邦に执いても小児尿道撮影関する文献梳非常に少な く, 僅かに各尿道疾患, 神経因性膀胱に数例行なわれて いるのみである (市川 ${ }^{50) 511}$, 辻等 ${ }^{101)}$, 山本 $\left.{ }^{111}\right)$.

造影剤注入には Brodny ${ }^{3}$ ) 法特殊器具 (冠状溝で陰茎 を固定する装置) を使用しているが, 私は $20 \mathrm{cc}$ 注射器の 先に約 $3 \mathrm{~cm}$ の細いネラトンを連結し，そのネラトンを尿 道内に㨂入することにより陰茎の固定と造影剤の漏出防 止に役立つた。造影剤络その目的より高粘稠性で，しか む水溶性, 浸潤性のあるものが望まれるので (Morales \& Romanus $^{77)}$, 山本 ${ }^{111}$ ), Pyraceton C 学使用した。

B) 膀胱尿管逆流現象について

膀胱および尿管の解剖学的構造と生理的機能により膀 胱内容の尿管への逆流が阻止されるので, 健康成人では VUR は発現しないと云うのが今日の見解であるが, 幼 児においては健康膀胱といえどもその可能性を推論する 者も多く(堀尾 ${ }^{37738(39) 40141142)}$, Stoeckel ${ }^{86)}, \mathrm{Kreschmer}^{58}$, Gibson $^{29)}$, Lowsley \& Kirwin ${ }^{66)}$ ), 又正常膀胱といえぞ も麻酔時には VUR が生ずると説く者もある(Graves \&

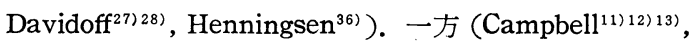
Stewart $^{92) \text { 93) }}$, Martin $^{78)}$ は正常小児ではその可能性はな いとしている．かょうに小児に捛ける VURに関して性 検討の余地が少なくない.

1）頻度

小児に抬けるVURの発現について快賛否両論があり 未だ定説はないが，いずれの研究者も成人に比して発現 し易いとと浪認め, Comarr \& Bors ${ }^{15)}$ は1083例中13.3 $\%$, Campbel1 ${ }^{12)}$ ( 722 例中 $11.9 \%$, Pasquier et al. ${ }^{82)}$ は 341 例中 $12.6 \%$, Forsythe \& Wealan ${ }^{24)}$ は 445例中 $13.7 \%$ に認めている。私怡76例中 9 例 $(11.9 \%)$ に認め たが，乙れは諸家の成績と略々一致している.

Comarr \& Bors ${ }^{15)}$ 快発現側について, 右側の方が左 側より頻度が約 1.5倍高いとしているが，その根拠は明 らかでなく, 自験例では両側 2 例, 右側 4 例, 左側 3 例 で左右差は認められなかつた。

特殊疾患に打付発現頻度をみると, Uson et al. ${ }^{102)}$ は下部尿路閉塞の $66.9 \%$, Bumpus $^{2)}$ は腎孟腎炎の18.9 $\%$, Bors \& Comarr $^{5)}$ 快脊髅損傷の $23.1 \%$, Bunge ${ }^{8)}$ は神経因性膀胱の $22.2 \%$, 下部尿路閉塞の $32.1 \%, \mathrm{Kjell}-$ 
berg et al. ${ }^{64)}$ は遺尿症の $5 \%$ と報告し，私の研究では 症例数が少ないため上記の成績と比慗するととは困難で あるが，第13表に示す如く神経因性膀胱 $(50 \%)$, 尿路感 染症 $(16 \%)$ に同様高率の発現を及，遺尿症に扮いても 5. 5\%と近似の值が出ている. ととに注目すべきこと沈 包茎の $50 \%$ VUR の発現をみたととである．高度の包 茎の場合には著明の尿の流通障害があるので下部尿路通 過障害のＩ型として解釈されるが, 現在までこの種の報 告に接しないので更に原因を究明したいと考えている.

第13表

\begin{tabular}{|c|c|c|c|}
\hline & 男 & 女 & 計 \\
\hline 遗 尿 症 & $1(4.7 \%)$ & $1(6.6 \%)$ & $2(5.5 \%)$ \\
\hline 尿路感染症 & $2(20.0 \%)$ & $2(13.3 \%)$ & $4(16.0 \%)$ \\
\hline $\begin{array}{l}\text { 神経因性膀 } \\
\text { 肬 } \\
\end{array}$ & & $1(500 \%)$ & $1(50.0 \%)$ \\
\hline 包 荠 & $2(50.0 \%)$ & & $2(50.0 \%)$ \\
\hline 計 & $5(13.1 \%)$ & $4(10.5 \%)$ & $9(11.9 \%)$ \\
\hline
\end{tabular}

2） 発現時間と程度

Comarr \& Bors ${ }^{15)}$ は尿管の輪状筇が VUR の防止的 役割を果し，なるべく上部尿路にまて VUR が及ばない ように作用していると述べ, 堀尾 ${ }^{37}$ は VURを第 1 度か ら第 3 度に分け, 第 1 度は骨盤胿を出ないもの, 第 2 度 は腸骨櫛を越えるもの, 第 3 度は腎盂にまで達するもの と規定し, 膀胱内圧と腎孟尿管内の圧力との差にょりこ れらが生じ, 第 3 度へと進むにつれ尿管は緊張性を失い 1 本の中空管にすを゙ないうになつていると記載してい る.

この分類に従い自験例を観察すると, 第 1 度逆流が 4 例, 第 2 度逆流はなく, 第 3 度逆流が 5 例であり, 更に 同一症例に执いても時間と共にその高さに变動を及せ, 尿貯溜により膀胱内容が多くなつても必ずしも VUR が 上部に及ぶとは限らない，又発現時間を観察すると黒田 ${ }^{612}$ の記載する直後型，持続型，遅延型がみられる．との 事恃間と共に VUR の発現形式に消長があるととを示 し，例えば症例 4 では同一条件での 2 回の撮影により異 つた型を示し, 症例 3 では時間の経過と共にVUR は上 部にまで波及し，逆に症例 7では VUR が一時軽度とな り，その後再び高度に出現している. 又症例 1,4 , 5, 6 では一度生じた VUR が次の撮影では消失してい る. 即ち従来の直後撮影の及で，症例 $1,2,3,4$, $5,6,7,9$ の7例のみに認められ, 症例 6,8 の 例 では見逃されている. 又症例 3 の如き右腎㙉炎の頻回再
発は，直後撮影で第 1 度逆流を示したものが時間の経過 と共に第 3 度逆流に進んだことに上り証明される。か上 に VUR の時間的消長の追求快極めて重要て, 延引性撮 影の有する 1 つの大な利点と云いうる.

3）残尿との関係

VUR 陽性群 9 例中 6 例 (66.6\%), VUR 陰性群67例 中 8 例 $(11.9 \%)$ に残尿を認めたが，陽性群に必ずしも 残尿があるとは限らず, Bunge ${ }^{8)}$, Bors \& Comarr $^{5)}$ は 残尿と VUR との関係儿法特異性はないと述べ, Stew. $\operatorname{art}^{922}$ 快尿管への排尿があるために, 残尿測定には排尿後 2 分を経過した後に行なうべきである強調している.

自験例では VUR 陽性群儿高率の有残尿例を認めた が, 残尿の多宑と VUR との間には関連性がなく, 又残 尿を有する症例中 1 例にのみその原因と思われる尿道狭 窄を認めたが, その他に恔変化がなかつた。

4) 静脈注射腎盂撮影 (IP) との関係

VUR 陽性群 9 例中 8 例に施行し, その中 5 例は機能, 形態共に正常と思われる所見を呈したが，2 例汸軽 度の機能低下, 1 例汸高度の機能障害を示した。これに 対し VUR 陰性群15例（遺尿症13例, 膀胱炎 2 例) では 全例に正常所見を得た.

この IP と VUR との関係について, 堀尾 ${ }^{39}$ は Constantinescu の云う Blasen-Ureter Zeichen 所謂造影 剤遺残現象の認められるもの, 即与上部尿路の運動機能: が緩慢又忺欠如している例に VUR が多いと述べている が, 自験例でも上部尿路の運動機能減弱例に VUR の発 現をみた。然し正常所見を呈する症例にもVUR の発現 をみた。

IP で異常所見を得た例住腎結核と水腎症の 2 例のみ て, 殆どが IP 正常例に VUR の発現をみたととは, 延 引性撮影の有用性を物語るものである. Fulton ${ }^{23}$ は IP で変化がないものにこそ延引性撮影の必要性があると説 き, Martin et al. ${ }^{78)}$ 注 VUR 陽性14例中 3 例にのみ. IP で異常所見を認め，他怯正常所見であつたとし， Leadbetter ${ }^{70)}$ は上部尿路を知る上に IP は重要である が，その所見は常に正確な状態を示すとは限らず，IP の所見にかかわらず VUR を暗示する臨床症状を呈する 場合に延引性撮影の必要なととを強調し，上部尿路のみ を念頭に执いて手術をすると失敗すると述べている. Hutch $^{45}$ は VUR で得た腎孟像と IP の像は所見が異る 場合があるととを指摘し，IP では単に腎から尿管，䁤 胱へ液体が流れるのに反し，下部亦らの高い圧，多量の 逆流では尿管壁の代償不全のために極端に拡張すると 
し，ての方が自然の姿であると述べている．自験例の症 例 7 は明らかにてれを証明している。

1960年シカコで開催された American Urological Association の VUR に関するシンポジウム ${ }^{94)}$ に抬いて, VUR の観察には延引性撮影々排尿時撮影が最も適して 打り，IP はあくまで補助的手段にすぎないと結論され ている.

5）膀胱鏡听見との関係

VUR 陽性群 9 例中 6 例に膀胱鏡検查を施行し, その 1 例仙高度の肉柱形成拝よび尿道狭窄を認め, 1 例では 膀胱粘膜の発赤が著明で尿管口を確認出来なかつたが, 他の 4 例には膀胱粘膜捛よび尿管口に異常所見を認め ず, VUR と膀胱粘膜, 尿管口の状態との間に特殊な意 義沈見出しえなかつた。

Campbell ${ }^{122}$, Stewart ${ }^{921}$ は膀胱鏡所見と VUR の間 には関連性を見出さず, 内視鏡検查で生理的に充分機能 があると思われる尿管口に VUR の発生をみ，全く機能 が久如していると思われる gaping golf-hole type にも VUR の発生をみないと記載している.

6) 膀胱内圧との関係

膀胱内圧はネラトンカテーテル ( 5 〜 7 番) を尿道へ 捚入し, 佐藤式膀胱内圧測定器 ${ }^{89990)}$ を使用して測定し た.

VUR 陽性群 5 例, 陰性群10例に膀胱内圧検查を実施 したが, 陽性群の 2 例に緊張過度膀胱, 1 例に緊張低下 膀胱が示され，陰性群の 3 例に緊張過度膀胱が示され た.

堀尾 ${ }^{37)}$, Henningsen ${ }^{36)}$ は膀胱は内容の増加により利 尿筋が能動的に収縮するまで膀胱内圧を一定に保つと述 べ, Graves \& Davidoff ${ }^{28)}$ はこの受動的な圧の間はVUR が生ぜず，利尿筇が収縮して始めて VUR が生ずると 記載している。私の成績では尿管膀胱移行部に括ける尿 管内圧々膀腅内圧との差により VUR が生ずると云う単 なる力学的な考え方は否定され，膀胱内圧が低い間にも VUR が生じた.

䁤胱内任と VUR との関連性については賛否両輪があ 3, Marshall ${ }^{79}$, Campbell ${ }^{12)}$ は密接な関係があると 一, Stewart ${ }^{93)}$, Pasquier et al. $^{82}$ は余り重要視していな い. 膀胱内圧は膀胱内注入量は勿論, 注入液の温度, 插 入したネラトンカテーテルの大きさ, 尿道膀胱粘膜の過 敏性によつて変動するが，小児では驚愕，恐怖などの 精神的要素に左右され易い. 私の成績では VUR 々膀胱 内圧との関連性が認められなかつたが, この判定には更
に慎重を期すべきで，膀胱内圧上昇もVUR 発生の一因 子と考えられる.

\section{7）排尿時尿道膀胱撮影との関係}

Finlay $^{26)}$, Hutch ${ }^{46)}$, Gudbjerg et al. ${ }^{32)}$,Christensen等 ${ }^{16)}$ 纷排尿時撮影が VUR の描出法として最も優れてい ると述べ次の如き見解を示している．尿管ならびに膀胱 の運動相転換が生理的に整然と行なわれ，尿管の霹動運 動のある間は膀胱内圧は膀胱壁の伸展により上甼せず, 利尿筋の収縮により膀胱内圧の上昇を来たすが，その際 膀胱尿管の神経反射により尿管の蠕動運動が一旦停止し て上昇した膀胱内圧が直接尿管へ影響を及法さぬような 生理機構が存在する. 然し神経反射の失調, 膀胱壁の変 化汇より膀胱内圧が異常に上昇し，尿管口弁機構の閉鎖 不全が存在する時，排尿時撮影により VUR が示される としている．然しこの方法は実施が困難であるのが難点 である.

Jones \& Headstream ${ }^{55)}$ 《延引性撮影と排尿時撮影 を比較し, VUR の発現頻度は両者同様であると述べて いるが, Pasquier et al. ${ }^{82)}$, Forsythe \& Wealan ${ }^{24)}$ は 排尿撮影の方が発現頻度は大きいとしている. 自験例で VUR の発現をみたものは19例中 1 例の及で, 延引性撮 影で VUR を示した他の 3 例败排尿時撮影では陰性て, 延引性撮影の方が発現頻度は高かつた。然し自験例の VURを生じた 1 例仕，延引性撮影飞比し VUR が高度 に且つ両側に発現した。.てれは恐らく膀胱壁，尿管口附 近の浮腫, 浸潤の程度に左右差があつたためと考えられ る. この例は排尿終末時に撮影されたものであり, 他の 18例梳排尿最盛時の撮影であることから，或いは撮影の 時期を選べば更に何例かに証明し得たかも知れない。乙 の意味に扮いて撮影の時期を考慮する必要がある。

\section{8）原因について}

VUR の原因に関しては種々検討されているが定説は ない. Hanten et al. ${ }^{49}$, Jones \& Headstream ${ }^{55}$, Pasquier et al. ${ }^{82)}$, Forsythe \& Wealan ${ }^{24)}$, Stewart ${ }^{929)}{ }^{93} / \mathcal{L}^{2}$ 膀胱頝部閉塞を第一義に主張し, Hutch ${ }^{44) 46)}$ ( 4 膀胱壁 内尿管の支持筋の欠如, 即与 Waldeyer鞘の損傷, Talbot \& Bunts ${ }^{98}$ 恃尿管口の歪み之硬化, Jannacone \& Pan$z^{2}$ ironi $^{54}$ 海短い壁内尿管と尿管口部の解剖学的異常に原 因を求め, 特に Marshall ${ }^{79)}$ は壁内尿管の長さと直径と の比を調べ, 正常では：1であるが $2 ： 1$ 位に長さが 短縮していると述べ，更に膀胱内圧上昇をも強調してい る. Kretschmer \& Hibbs $^{58)}$, Graves \& Davidoff ${ }^{27)}$ は 膀胱壁自体の変化, Helmholz ${ }^{35)}$ は尿路感染, Bors \& 
Comarr ${ }^{5)}$ は神経失調を最む重要視しているが，いずれの 者もそれのみを主張せず，壁内尿管の直径，長さ，屈曲 性, 斜行性, 支持組織の欠陥, 膀胱内圧の上昇, 感染, 下部尿路閉塞など多数の因子が相互に関係していると考 えている。

延引性撮影, 排尿時撮影, 尿道膀胱撮影, 更に静脈注 射腎孟撮影を併用してレ線学的に VURの原因を明確に し得たのは症例 7 の神経因性膀胱のみで, この症例は仙 骨部春椎披裂の手術を受け，尿道狭窄を認め，高度の肉 柱膀胱像を示し，IP では水腎症を呈した。他の 8 例は レ線学的には勿論，他の諸検査によつてもVURの原因 を確認出来なかつた。諸家の研究を綜合すると，第 3 図 の如き原因が考えられ，極く僅かの変化が相互に関係し 西つてVUR を惹起するに至る。

自験例を検討するに, 膀胱炎症例は恐らく内視鏡的に 性確認出来ない膀胱壁の浮腫，浸潤が尿管口に及び，そ の尿管口弁機構が障害されたものと考えられ，延引性撮 影で偏側性であつたものが排尿時撮影で両側に現われた の注, この浮腫, 浸潤の程度が左右で異り, Marshall ${ }^{79}$ の云う如く相対的に 1 側が他側の尿管口の状態变え 得たものと考えられる. 㛑孟炎症例は尿路感染により尿 管口に变化 が 来たものか, Campbel1 ${ }^{12)}$ の云う如く緊張 低下膀脱，無緊張性膀胱では尿管口にも同様の緊張低下 乃至欠如があるというょうな機序により生じたものかは 判然としない. 腎結核症例は病変が進行し壁内尿管口の 硬直, 尿管口周囲膀胱壁の硬化が一定の範囲を越え, 却 つて尿管口腔の縮小，狭窄を来たしたと同時に健側尿管 ロへ変化が及んだことを示すものとして説明される．遺 尿症例冲神経性失調によるものと考えられるが，その中 1 例が尿道拡張により VUR の消失をみたので, 膀胱䅡 部, 尿道に軽度の浮腫, 或いは狭窄があつたものと思わ れ，下部尿路通過障害と云了ことも否定出来ない。神経 因性膀胱法尿管口閉鎖機構の神経性失調，ならびに感染 刺战による内圧上昇或い恰染そのものによると考えら れる. 包茎症例は 2 例共他のレ線検查では異常を認めな かつたが，その中 1 例は形成手術後 VUR の消失をみて 心るのて, 包茎のための尿路通過障害も考えられる.

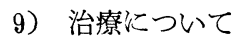

幼若者に抢汀る VUR 出現を異常とするか否かについ ての定説はないが，VUR を認めをならばそれを治療す べきであるという点では意見が一致している.VUR の 治療はその原因が多種多様であるため種々検討されてい る. Pasquier et al. ${ }^{82)}$, Forsythe \& Wealan ${ }^{24)}$, Bors
\& Comarr ${ }^{5)}$ 注尿路感染の防止之管理によりある程度改 善をみると云い, Lattimer et al. ${ }^{68}$ は感染をなくする 手段として tripple voiding を行なつている. 即ち小児 に昼間 2 時間毎, 夜間 2 回の割て 2 分間隔で 3 回排尿さ せる. との方法注簡単且つ効果的で膀胱のみならず尿 管腎盂をも空虚になし得ると述べてい. Leuzinger et al. ${ }^{69)}$ もの方法を行ない可成りの成績を得ている.

Stewart ${ }^{93)}$, Bunge ${ }^{7 / 8)}$, Bors \& Comarr ${ }^{5)}$ 怪尿道的或 い膀胱切開による膀胱頚部切除, Hutch et al. ${ }^{45}$ ) 胱尿管新形成術 (neostomy) を薦めているが, Bors \& Comarr ${ }^{5)}$ は原因が明確になるまでは無暗に neostomy を施行すべきではないと警告している.

自験例の場合，尿路感染症の 4 例中 2 例注抗菌剂使用 により 1 週後に, 1 例は tripple voiding 导行ない 1 カ 月後に, 遺尿症 2 例中 1 例はブジーによる尿道桩張导行 ない, 夫及症状改善と共に VUR の消失をみた。他の永 路感染症 1 例と遺尿症 1 例以経過の追求不能であつた。 神経因性膀胱の 1 例は尿道拡張と留置カテーテルで 1 カ 月後に上部尿路拡張の程度が改善されたが依然として VUR が残り, 包茎 2 例中 1 例柱形成手術後 1 力月で消 失したが，1例は手術後も依然 VUR を認めている.

かくの如く尿路感染症例に招ける細菌感染, 或いは尿 道拡張により改善をみた遺尿症例や形成手術施行後治瘜 した包茎例に推定される通過障害などのように, 原因が 単純, 明膫な場合には治療は簡単でその成績も良いが, 神経因性膀胱，包茎の他の 1 例の如く原因が複雑，不明 の場合には治療注困難である. 要するに諸家の述べる如 く詳細な検査により先ず原因安明確にすることが最大の 治療法であると云い得る。

C) 膀胱像について

小児の膀胱像注種々,の要素に左右され, 正円形乃至卵 円形を呈することは少ない，その最大の要素は Campbell ${ }^{12)}$ の云了膀胱充満度で, 不完全に伸展された膀胱像 は膀胱外圧, 特に結腸, 直腸内容に影響されて不正形を 示す. 殊に延引性撮影では充満度が不充分のため, 膀胱 像自体を観察することは余り意義がないように思われる が, 漸増的尿眝溜による膀胱の生理的な拡張变化の観察 には最も適している。

1）耽骨との位置的関係

膀胱下縁は時間的推移にかかわらず, その位置は変動 しない. Kjellberg et al. ${ }^{64)}$ は小児膀胱の位置に関し， 新生児㧍よび幼児は膀胱下縁が恥骨より上部に存する が, 年令の增加と共に潮次膀胱下縁が下方に移り恥骨と 
僅水重なると述べ，场尾 ${ }^{38}$ は小坚膀胱像は概して恥骨 上り上にあるが成人では恥骨に重なるとし，成人では恥 骨と膀胱下縁は平均 $1.4 \mathrm{~cm}$ 重なると記載している.

Rothfeld \& Epstein ${ }^{84}$ 《乳坚期の膀胱以腹部蔵器で, 部 分的に尿膜管と関係が女つて小骨船䐦内に充分固定され ていないと説明している.

自験例では第 4 表に示す如く，男児女坚共 5 才以下で 法膀胱下縁が恥骨々重なるもの恔 1 例もないが，10才以 下になる己男児 22 例中 6 例 $(27.2 \%)$ ，女児 13 例中 1 例 ( $7.7 \%)$ となり，更に14才以下となると男児10例中 3 例 $(30 \%)$ ，女巟12例中 4 例 $(33.3 \%)$ と增加し，乙机方 の報告と一致する。

2）膀胱像の拡大度揖よび変化

膀胱像の搪大决上緣の重直下向が最も著明で, 正中線 より左右以向つては放射状に拡がる。藤浪 ${ }^{20)}$, 日高 ${ }^{34)}$, 尼形 ${ }^{80}$ 法正常膀腅につき, 膀胱空虚時に以膀脱上緑が陮 凹して泵状の影像老呈し, 周囲蔵器に影響されずに膀胱 内容が漸增与る場合, 膀胱像の左右径, 縦径共平等に应 火し增量に上る㧙張の負担を腤脱壁平等に受け，その結 果膀胱像快上縁が突出して来て円味を带び卵円形に近づ くと述べ，尿意が現われるまでは横長い卵円形，菱形 であるが，膀胱壁が緊張し排尿比際しての腹压が加わる と上下に長い紡鎾形在呈与るとしている。三矢 ${ }^{72}$, 高安 - 西浦 ${ }^{99}$ 100) 纱正常排尿時像を, 縦横同程度飞短縮与方名 場命, 横が縦以上に短縮する場合, 縦が横小り著しく短 縮する場合の 3 型に分類し, 弛緩期々り緊張期に至る上 必ず横径が短縮し縦径が增大すると云つている。

膀胱容量の約 $1 / 3$ 量の膀胱像 汶円形委示例牥少な く, 殆どが上縁が平坦な半円形で横径が長く輪柕屾鮮明 で平滑である. 又不正形を示すものの多くは恰も梯形を 呈し, 怂性膀胱炎の症例では辺縁が鋸歯状を示すが, 己 の半数以上㳊時間の経過にかかわらず鋸㐘状縁が依然上 して残つた (第 6 表).

この小うな膀胱像が 60 分の㭙間経過で漸次円形に近づ くが, 第 5 表心示与如く約 $85 \%$ は縦径の搪大度が横径の 拡大度に比し 1.2〜 1.5倍となり, 先に述べた排尿に上 る短縮の状態打上び造影剂の增量に上る膀胱像の拡大の 状態の記載と異なる. 久 1.5 倍以上を示した10例を検討 すると，途中尿意在泝元心症例梳半数強の 6 例に認めら れ，恐らく60分後に注利尿筋が或る程度作用したためと

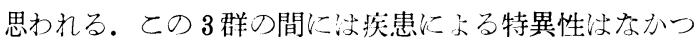
たが, 下部尿路正常の13例で恣，いずれも 1.2〜 1.5の 範囲内にあつたことょり小児正常膀胱の生理的拡張様式
汶60分の間に縦径が横径の $1.2 \sim 1.5$ 倍に拡大与るもの と思わ狄る。

直後撮影像で左右非刘称性守示したもの纹71例中12例

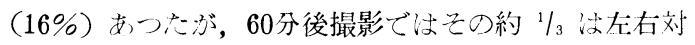
称性圭示し, 約 $1 / 3$ 㳉反対側が搪大し, 60 分後撮影で直 後撮影々同様の左右非対称性在示したのは 5 例 $(7 \%)$ にすぎなからた（第７表）。

この事洪膀胱像が膀胱外因子に非常に影響され易いこ

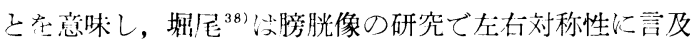
し，正中線に一致些る縦径に対しては左右面積の大小が 女るが，膀胱このものの最大縦径ならび飞最大横径心刘 して汸，左右，上下の面積が等しい場合があると述べて いる. 自験例でも空虚時, 充満㭙共に堀尾の定義が該当 し, 彷来の正中線基本上する考え力心门も，最大縦径 上最大横径在基本とする万が妥当と思わ机る。

3）膀胱澒部の漏斗状突出像

Campbell ${ }^{12)}$ 《膀胱充満度の如何に心心小らず膀胱下 縁は下ううの面を向计た平滑な縁を形成し，カテーテル 挿入なくしては内尿道口は明瞭でないと述べている。自 験例で第 8 表に示す如く遗尿症患者の約 $20 \%$ に膀胱䅡 部の漏斗状突出をみた.

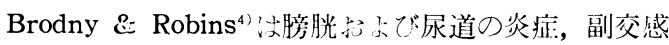
神経失調に由来する膀胱レ線像注, 膀胱頚部の囊状, 漏 斗状突出を示すと記載し，遺尿症群にそれをみている. Siekiwicz ${ }^{87)}$ ( 遗尿症患者に膀胱鏡検查告施行し，内尿 道括約筋弛緩例では膀胱充満時に膀胱頚部が弛綏開大し ている事実を示し, McFadden ${ }^{71}$ はこのように膀胱頝部 が開大している型の遗尿症患者に対して尿道壁形成手術 を施行して成功している. Muellner ${ }^{74)}$, Hodgkinson ${ }^{47)}$, Jeffcoate \& Roberts $^{53)}$ 汶婦人の intrinsic voluntary muscle の弛緩に基ずく内尿道口の漏斗状突出を認め, 急迫尿失禁々関係づけようとしている. Kjellberg et

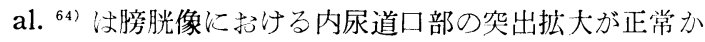
病的か法決定し難いが, 主に遺尿症患者にそれが観察さ れるところから，恐らく内尿道括約笳に関係あるので洁 ないかと推定している. 又山際 ${ }^{110)}$ は結核膀胱の $40 \%$ に 内尿道口部の漏斗状拡張を見出している.

Wesson ${ }^{106)}$ とよ扎ば仙䯣のII IV 上り出た副交感神経 以骨盤神経老経て膀胱，尿道の平滑筋老支配し，その平 滑筋は強力以膀胱三角部から内尿道口を囲及ながら前立 腺部尿道の上 $2 / 3$ に本で達し, 膀胱の強い括約作用在司 つている々述べている. この副交感神経障害時に膀胱頚 部が弛綏することから, 自駼例の漏斗状突出像を示した 
7 例飞つき潜在性㝓椎披裂ての関係古検討したぶ，特に 関連性は認內られなからた。然しとの漏斗状突出像は遗

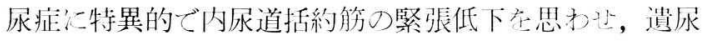
症の原因の1つ々考光られる。

D）尿道膀胱撮影飞よる氺道計測について

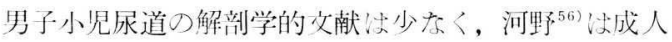
男子 50 例の剖検上り尿道固定部在前立腺部, 膜様部,

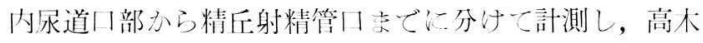

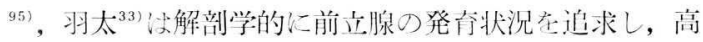
木沈初生児， 3 才， 9 才，12才 2 例の合計 5 例, 羽太心 4 力月小ら 12 力月走で 7 例, 3 才から 4 才寺で 5 例， 6 才から 9 才志で 3 例，11才 1 例の合計16例纪つ剖検上 り前立腺の大きさ学報告している。レ線学的纪い黑田 ${ }^{60)}$, 外塚 ${ }^{91}$ が成人前立腺在尿道撮影飞上り計測し, 又朴 下 ${ }^{57)}$, 田林 ${ }^{977}$ 《造影剂拄入量と尿道像上り成人の尿道の

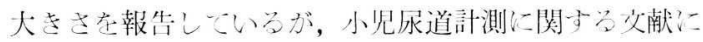
㳊末だ接しない。

自験例の計測值（第11表）在㮔封与る上，前古腺部尿 道の大部走占める Bの年令的発高洨，10才以下に比し14

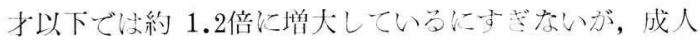

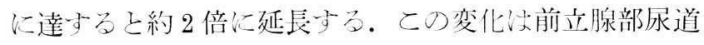
横径 $\mathrm{E}$, 精丘公横径Fについてもみられ, 高丸 ${ }^{95}$, 羽太

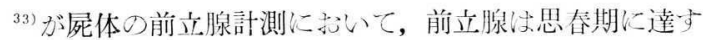
る穼では余り増大しないが思春期になると急速に発庁增 大すると結論した報告上一致する。しれに反し外尿道括 約筋圓の発育を示す C, 球部尿道D以年令上共汇漸增し 外陰部の発育と比例する。然し主として内括約朌層年示 すAは年令的に殆じ変化をみない. 又類宦官症患者の尿 道計測值は思春期以前の小児と類似し, 特に前立腺, 精 丘では殆ど小児と変化がないととは興味深い。

E）裸部尿道の形態について

小児尿道像上成人尿道像上省比較与る上, Morales \& Romanus $^{76777)}$ の記述する裸部尿道の形態が小児では全 例に非常に明瞭渵出されている(第36図, 第37図).

Hackworth $^{43)}$ は尿道撮影で造影剂の怂速な注入は外括 約筋部の攣縮を惹起し, 又間歇的な注入注後部尿道の不 完全充満となると記載しているが，自験例では撮影前の 尿道麻酔の有無に心かわらず，全例に殆ど抵抗老感ずる ことなく注入し得たので, Hackworth の云う尿道攣棭 の夕でとの裸部尿道の明膫な描出が得られたとほ考元ら れない。

Vernet $^{105)}$, Morales \& Romanus ${ }^{76) 77)}$, Beneventi \& Marshal1 ${ }^{91}$ 等が云つている如く, 前立腺下部から裸部上
第36図 11 才，男 遗尿症（注人洔尿道膀胱撮影）\|

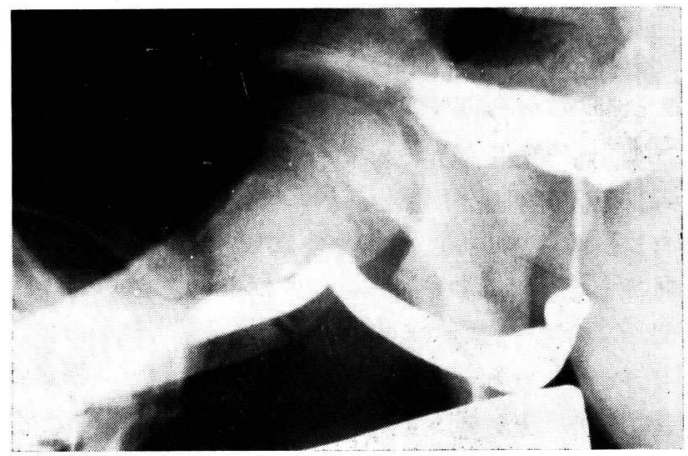

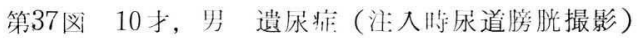

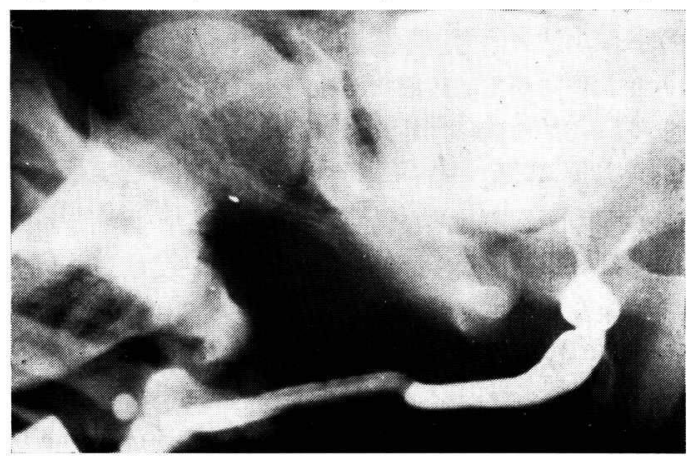

方に亘り存在する外括約筋層が，小児期には未だ外力に 䒧分抵抗するな゙けの厚さ有しないので，外尿道口ょり の造影剂注入少裸部尿道が異常に膨大し境界が明瞭 になるのではないかと推測される。然し疾患別, 年令別 に文て裸部尿道の形態には特異性を胃出し得なかつた。

F) 膀胱䅡部の形態について

第12表の如く膀胱頚部の分類では第 II 型が最も多数を 占め，特に正常例古含吉非遗尿症群では 2 例在除くすべ ての症例が，又遺尿症群でも半数以上がこの型を示した ことは，との型が小归に扮怙る標準型であるととを証明 している．実際第 II 型は成人男子飞及られる正常型の縮 小上もいうべきもので, 内括約筋の発育が正常で適度の

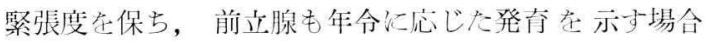

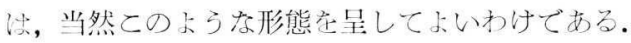

遗尿症群では標準型である第 II 型が半数以上存在する 之共に, 遗尿症の及にしか観察されない第 I 型（第 I 型 の非遺尿症群の 1 例谂急迫尿失禁で遺尿症類似疾患々考 える), 第型が $38 \%$ も存在し，明ら机性状の異なる 2

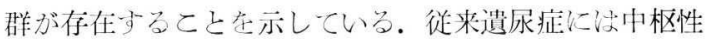
のものと，末梢性のものがあると考充られて挹り，山本 
111) も遺尿症患者に捛いて尿道レ線学的に膀胱頝部に形 態的変化を有し後部尿道の各運動機能に障害学有する群 と, 膀胱䅡部の变化を認めず後部尿道の各運動機能の略 々正常な群に分け, 前者を末梢性, 後者を中枢性のもの と見做しているが，私の成績もそれに一致している。

遺尿症群にみられる形態的特徵の第 1 次内尿道口部の 报張であり, 第 2 は精丘上部の短縮である. 即ち内尿道 口部の拡張は遗尿症群のみにみられる変化であり, 精丘 上部の短縮も遗尿症群 14 に対し非遗尿症群 1 と圧倒的に 多くを占めた，換言すれば，前者或は両者の合併が認め られた場合はすべて遣尿症ということが出来る。然し後 者のみの場合に問題があり，このととは第IV型と関連し てくる. 精丘上部の短縮のみを示したもの流遗尿症群で は 3 例で最も少なく, 第 $\mathrm{N}$ 型に属するが, 非遗尿症群に む1例あり，百分率よりみて顕著の差㹥認められないの て，ての変化のみで遺尿症が招来されるかどうか疑問で ある. 精丘上部に短縮がみられる場合, 前立腺の発育が 不良であることは推定出来る. 然しそれに平行して内尿 道括約筋にも発育不全ならびに機能不全があるかどうか は推定出来ない. この点に関し，200例の成人男子の遺 尿症患者を観察し前立腺発育不全を $80 \%$ に認めたという Sienkiwicz ${ }^{87)}$ の報告は, 精丘上部の短縮抢よび内尿道 括約筋の発育不全が多数存在するととを 示唆すると共 K, 内尿道括約筋の発育不全を伴わないものも少数ある ととを示している，それ故適当な方法即与骨盤底筇収縮 時尿道膀胱撮影或以注入後尿道膀胱撮影などの機能的検 索を行なえば，ある程度までとの2 群を区別することが 出来ると考えられる. その場合機能正常群将第 II 型の亜 型で, 機能不全群が本来の第 $\mathrm{I}$ 型と云い得る.

内尿道口の桩張が内尿道括約筋の発育不全或注機能不 全によるということには意義をさしはさむ者はなく，遗 尿症患者に执いて内外の研究者がこの変化を認めてい る. Brodny \& Robins ${ }^{4}$ は注入時尿道撮影を行ない, 遗 㽷症患者の精丘上部の形態を研究して副交感神経失調に 由来する内尿道括約筇の無緊張状態を示守精丘上部漏斗 状拡張を特異な点として報告している. 又 Fischer \& Forsythe ${ }^{22)}$ は排尿時尿道膀胱撮影で上部尿道の拡張, 特 に膀胱頚部の拡張を示し, 恰も神経因性膀胱の如き像を 呈する遺尿症群を報告している. 自験例でも排尿時尿道 膀胱撮影で遺尿症11例中 2 例に膀胱䅡部の桩張を認めて いる. Sienkiwicz ${ }^{87}$ 性遺尿症少女に膀胱鏡検査を施行し て膀胱䪹部が弛緩している事実を報告している.

G) 遺尿症に対する考察

Williams ${ }^{109}$ は泌尿器科医は遺尿症患者に打ける尿路
の小病変の役割をも注意せねね゙ならないと強調している が, 精神医学者の間では遺尿症の原因として器質的要素 より精神的要素を重視する傾向が強く, Levine ${ }^{67)}$ 等は 泌尿器科的検索は余分のものであるのみならず却つて望 ましくないと極言している.

器質的疾患としては, 包茎も無視出来ず, 遺尿症患者 中, 外尿道口狭窄を70\% (Winsbury-White ${ }^{1077}$ ), 6 27 $\%$ (Stockwell \& Smith $^{88)}$ ), 腔炎を50\% (WinsburyWhite $^{107)}$ ), 尿路感染を15〜25\% (Winsbury-White ${ }^{1077}$ ) それぞれ認め, 特に少女では膀胱三角部炎が最も普通 にみられ (Campbel1 $\left.{ }^{12)}\right)$, 尿道, 膀脱特に三角部の感染 から来る慢性膀胱過敏症を遺尿の原因として挙げている 者もある (O’Brien \& Mitchell ${ }^{11}$, Vulliamy ${ }^{103)}$ ). 又尿 所見正常例にも尿道, 膀胱の器質的変化を $70 \%$ に認め

(Winsbury-White ${ }^{107)}$ ), 疾患別に注尿道弁膜形成 0.5 $\sim 2 \%$ (Stockwell \& Smith $^{88}$, Winsbury-White ${ }^{107)}$ ), $30 \%$ (Fischer \& Forsythe ${ }^{22)}$ ), 尿道狭窄, 尿道浮腫 (Abernethy \& Tomlin ${ }^{11}$ ), 精丘肥大 (Tomas \& Hubbel1 ${ }^{16)}$ ), 膀胱䅡部疾患 (Brodny \& Robins ${ }^{4}$, Fischer \& Forsythe $\left.^{22}\right)$, 膀胱三角部の短摍 $\left(\mathrm{Cohen}^{14}\right)$ なぞが強調 され, Sienkiewicz ${ }^{87)}$ は 200例の成人男子の遺尿症中, $80 \%$ 亿前立腺発育不全を認めている.

この様な先人の業績を通覧すると, 遺尿症の原因怯個 々の症例括いて必ずしも一定せず, 従つて個々の症例 を詳細に研究して得られた成績を集積整頓するととによ り更に本疾患の病因論が解明される。私は延引性膀胱撮 影, 排尿時尿道膀胱撮影, 注入時尿道膀胱撮影を遺尿症 患者に実施し, 夫々多数例飞膀胱䁰部の漏斗状突出像之 精丘上部，内尿道口部拡張像を認めたが，これらの変化 を遗尿症の原因の 1 つとして挙げたい.

自験例で夜間遗尿を主訴とし，尿感染を証明した 3 例

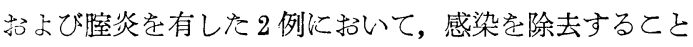
により症状の改善をみた。 又尿所見正常例中尿道狭窄が 1 例含まえ，尿道拡張により治瘾せしめえた，注入時尿 道膀胱撮影では尿道弁膜形成, 精丘肥大は見当らなかつ たが, 前者の検索には排尿時尿道膀胱撮影が最も優れて いるととは論を待たず, 後者の検査には精丘の大きさの 点で多分に主観が入り, Johnson \& Price ${ }^{52)}$ は精丘肥 大症の診断には尿道鏡が最も好末しいとしており，Brodny \& Robins ${ }^{4}$ 注尿道撮影における精丘像の大きさ, 形状により診断しているが, 更に研究の余地がある.

H） レ線障害とその防止法

レ線撮影に際し，被検者ならびに造影剤注入を実施す 
る術者のレ線被暴量を知るととは必要て, 特に小児を対 象とする場合には極めて重要である。

私はかよろな見地より，どの程度のレ線被曝量がある か, その防止法はどうあるべきか, どの程度防止が可能 であるかを研究する目的て, 延引性膀胱撮影, 注入時尿 道膀胱撮影の際の被検者ならびに術者のレ線被曝量を, 東芝ポケットチェンバー, 島津標準型線量計, 東芝直読 式梁部線量計を用いて測定した. 更に私の行なつた防止 法（被検者の陰囊部を厚さ $1 \mathrm{~mm}$ の鉛板で遮蔽し，術者汢 防護前掛を着用し，被検者と術者の間に含鉛ゴム布防護 策を置く)の効果を判定するために，防止法を施行した 場合と施行しなかつた場合を比較した。

延引性撮影掞よび注入時撮影に掞ける被検者, 術者の 各部のレ線被曝量は第14表, 第15表に示す如くである. 延引性の場合, 術者は撮影室上り遠ざかるから問題はな い.な抢この測定值は体格の良好な13～14才の男子につ いてのもので，乳幼児ではもつと数值は小さくなるもの と推測される.

第14表 延引性膀脱撮影 ( 1 回撮影) 撮影条件: $59 \mathrm{~K} \mathrm{~V}, 200 \mathrm{~m} \mathrm{~A}, 0.15 \mathrm{sec}$.

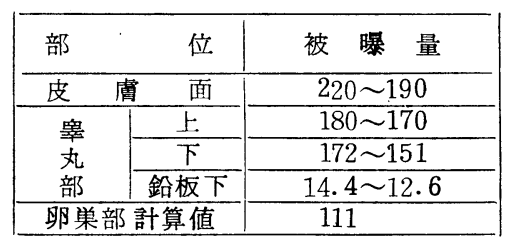

(単位 $: \mathrm{mr}$ )

第15表 注入時尿道膀胱撮影 ( 1 回撮影) 撮影条件: $63 \mathrm{~K} \mathrm{~V}, 200 \mathrm{~m} \mathrm{~A}$, $0.2 \mathrm{sec}$. 被検者

\begin{tabular}{|c|c|c|c|}
\hline 部 & & 位 & 被 曝 量 \\
\hline 皮 & 膚 & 面 & $660 \sim 450$ \\
\hline \multirow{3}{*}{ 辠丸部 } & & 上 & 510 \\
\hline & & 下 & 310 \\
\hline & & 鉛 板 下 & 26 \\
\hline
\end{tabular}

術者

\begin{tabular}{|c|c|c|c|c|}
\hline \multicolumn{2}{|l|}{ 部 } & 位 & 被 & 曝 量 \\
\hline 前 & 額 & 部 & & 11.5 \\
\hline \multirow{2}{*}{ 後頭部 } & & 右 & & 36.5 \\
\hline & & 左 & & 9.6 \\
\hline 辠 & 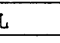 & 部 & & 7.7 \\
\hline \multirow{4}{*}{ 前膊部 } & \multirow{2}{*}{ 右 } & 上 & & 9.6 \\
\hline & & 下 & & 10.6 \\
\hline & \multirow{2}{*}{ 左 } & 上 & & 17.3 \\
\hline & & 下 & & 25 \\
\hline
\end{tabular}

(単位 : mr)
Weens et al. ${ }^{108)}$ の統計によれば, 腎膀胱部撮影の際 の被暴量治, 莘丸15〜 $140 \mathrm{mr}$, 卵巣部50〜 250 $\mathrm{mr}$ と なつており, Christensen ${ }^{16)}$ は延引性撮影の際には陰囊 部を遮蔽するととにより相当の効果が得られるが, 女子 では卵巣部の梁蔽は不可能であるから, 無意味な検查 は避けるべきであると主張している。，一方術者について は, 尿道撮影の際の医師の手部を測定した結果30〜 60 mr の数值を得たが, レ線中心よりなるべく遠ざかるように 注意しただけで $1 / 3 \sim 1 / 6$ に減量出来たと云つている. 私 の成績ては被検者の睪丸部を遮蔽した場合 5〜10\%まて 減量でき, 充分の効果が得られたものと考えられる. 然 しながら小児の場合は特に被検者 1 人当りの撮影回数を 少なくするように撮影法の選択に慎重を期さねね゙ならな w.

\section{VI. 総 括}

下部尿路通過障害の診断法として，レ線撮影法は内視 鏡検査法にみられぬ長所を有し確固たる地位を占めつつ あり，従来レ線撮影の技術的困難性む伴つて等閑視され ていた女子に执いてすら有力な検查法となつている.と ころが小児に执いては更に困難と考えられたため今日ま で殆ど未開拓の状態にある. 然しながら小児に抢ける限 りレ線撮影法は内視鏡検查法の遠く及法ない利点を有 し，下部尿路の変化を観察するに適している.

私は小児の下部尿路撮影法としての延引性膀胱撮影, 排尿時尿道膀胱撮影, 逆行性尿道膀胱撮影を採り上げ, これら撮影法を適当に組合せることにより, 正常例なら びに諸種疾患, 就中遺尿症について研究し種々の興味あ る所見抬よび新知見を得た。

各種の撮影法を実施するにあたり，小児に即した条件 を碓虑する必要がある。私忙造影剂の選択, 撮影前の尿 道粘膜麻酔の実施, 注入器の考案などにより, 排尿時撮 影を除き概ね満足すべき成果を収めることが出来た。

延引性撮影では VUR について詊細に観察すると共 に, 膀胱像を検討した.

VUR の発現頻度は $11.9 \% て ゙$ 尿路感染症に高率を示 し, 発現形式に注直後型, 持続型, 遅延型が存在するこ とを確認した. 又 VUR と残尿, 膀胱鏡所見, 膀胱内圧 との間には因果関係は認められず，IP に沶いて VUR 発現側に機能低下をみるものが $1 / 3$ に認められた. 又包 茎患者中かなりの比率に VUR の発現をみたが, 過去に 掞いてとの種の報告はみられず, VUR の成因考察上注 目に值する。

次に小児膀胱像については現在まで殆ど注目されてい 
ないのて, 私は膀胱の生理的拡張過程を示す膀胱像の推 移を研究した。 その結果膀胱の生理的拡張に際し, 膀胱 下縁は常に一定位を保ち, 空虚時には盃状, 半円形を呈 するが，垂直方向に最も著明に拡大し，全体として放射 状に拡がる. この際縦径と横径との拡大度の比は60分間 で 1.2〜 1.5の範囲内にあるが, 尿意を訴えない限り最 大縦径が最大横径より大とはならない。

又膀胱像と恥骨との位置的関係には年令的差異があ り，幼若者は両者が隔つているが，年令增加に伴い膀胱 像の下降がみられた。

延引性撮影に抢ける膀胱頝部の漏斗状突出像, 排尿時 撮影に打ける膀胱頝部, 内尿道口の拡張像は, 急性膀胱 炎の尿意促迫例を除き, 遗尿症群洔特徵的所見と云うこ とが出来る.

小児に掞ける尿道撮影は排尿時撮影が主流を占め, 逆 行性撮影に関する報告は殆ぞ見当らない。私は斜位注入 時尿道膀胱撮影を実施し，レ線学的に尿道各部の計測を 行なつて年令的な観察を試及，前立腺部尿道注幼児，小 呪期には発育が顥著でなく, 思春期以後に急速に発育す るのに対して，他の尿道各部は体格の発育と比例するこ とを証明した。

次に斜位注入時膀胱䅡部像を 4 型に分類したが, 正常 例を含む非遗尿症群は殆ど第 II 型を示したのに対して, 遗尿症群に执いては第 II 型の他に，第 I 型，第吕型とい 了内尿道口部の拡張, 精丘上部の短縮或はその両者を合 併する内尿道括約筋の発育不全ならびに機能不全群の存 在が示された。

小児に打ける下部尿路レ線撮影の際には，性腺保護と いう重大な問題があるが, 私は陰囊部を厚さ $1 \mathrm{~mm}$ の鉛板 て遮蔽することにより充分に目的を達し得た。

延引性撮影は VURの影響に適するのみならず, 膀胱 の最も生理的な拡張状態を知る上に貴重な所見を与える 点法特筆すべきである. 然しこれのみては膀胱頝部を中 心とした形態的変化汸つかず，その際には引続き排尿 時撮影或は注入時撮影が必要となる，小児では前者は実 施が非常に困難であるのに反し後者は従来云われる程困 難でなく, 適当な条件を顧慮すれば非常に実施が容易て 且つ診断的価值が大きい点より，小児下部尿路の断診法 として極めて有用視される。乙れらのレ線撮影法を症例 に応じて適宜組合せ実施することが，小児下部尿路疾患 の解明手段として不可欠の方法であると信ずる.

\section{VII. 結 語}

小児下部尿路のレ線学的研究に执いて, 延引性膀胱撮
影, 排尿時尿道膀胱撮影, 逆行性尿道膀胱撮影を夫《 76 例, 19例, 88例に施行して形態学的検索を行なうと共 に, 一部の例につき併せて検討し次の成績を得た。

1）延引性膀胱撮影により膀胱尿管逆流現象を観察 し, 発現頻度, 発現形式, 臨床検查所見との関連性なと において，先人の報告と略々一致する成績を得た。な拉 包茎患者に発現例をみたことは, 従来記載がなく注目に 值する.

2）延引性膀胱撮影像が膀胱の生理的桩張状況を明確 に示す点に注目し, 膀胱像の時間的推移につき研究した 結果, 膀胱の生理的拡張には一定の形成があり, 年令的 に特異性のないととを認めた。

3）延引性膀胱撮影飞招ける膀胱頚部の漏斗状突出 像, 排尿時尿道膀胼撮影飞括ける膀胱䅡部むよび内尿道 口の昖張像柱，遺尿症群に特徵的所見である。

4）斜位注入時尿道膀胱撮影により尿道各部の計測を 行ない, 年令別の数值を得ると共に, 各部の発育過程に ついて興味ある所見を得た。

5）斜位注入時膀胱䅡部像を 4 型に分類し，遺尿症に 内尿道括約筋の発育不全ならびに機能不全を示す特異型 に属する群が存在することを証明した。

6）小児下部尿路レ線撮影に打ける被暴量を測定する と共に, レ線障害保護対策について記述した。

7）注入時尿道膀胱撮影は小児に执いても条件を顧虑 すれば実施が容易であり，且つ診断的価值が大きい点よ り，極めて有用な検査法である.

8）小児下部尿路疾患の解明手段としての延引性膀胱 撮影, 排尿時尿道膀胱撮影および注入時尿道膀胱撮影の 重要性を認める己共に，乙れ等三者の適宜の組合せが最 良の方法であるととを強調する。

擱筆するに当り，終始御懇篤なる御指尊と御校閲を睗 つた恩師黒田恭一教授に東心上り感謝すると共に，種々 の御援助を与克られた山本助教授はじめ教室員諸兄, レ 線撮影に協力された村本技師に深謝する.

本論文の要旨は, 第49回日本泌尿器科学会総会(1961), 第 199 回日本泌尿器科学会金沢地方会 (1960) に沶いて 発表した。

（本論文は金沢大学審査学位論文なることを付記す る).

\section{文献}

1) Abernethy, A.C. \& Tomlin, E.M.: J. Urol., 72, 1163, 1954.

2) Bumpus, H.C.: J. Urol., 12, 341, 1924. 
3) Brodny, M.L.: J. Urol., 46, 350, 1941.

4) Brodny, M.L. \& Robins, S.A.: J.A.M.A., 126, 1000, 1944.

5) Bors, E. \& Comarr, A.E.: J. Urol., 68, 691, 1952.

6) Boyce, W.H. \& Haris, J.A. \& Vest, S.A.: J. Urol., 70, 969, 1953.

7) Bunge, R.G.: J. Urol., 70, 729, 1953.

8) Bunge, R.G.: J. Urol., 71, 427, 1954.

9) Beneventi, F.A. \& Marshall, V.F.: J. Urol., 75, 273, 1956.

10) Burns, E. \& Ray, E.H. \& Morgan, J.W.: J. Urol., 77, 733, 1957.

11) Campbell, M.F.: Amer. J. Dis. Child., 39, $386,1930$.

12) Campbell, M.F.: Clinical Pediatric Urology, W.B. Sanders Co., 1956.

13) Campbell, M.F.: J. Pediat., 35, 169, 1949.

14) Cohen, D.L.: J. Urol., 57, 331, 1947.

15) Comarr, A.S. \& Bors, E.: J. Urol., 74, 59, 1955.

16) Christensen, E.R.: Acta. Radiol., 52, 426, 1959.

17) Dean, A.L. \& Lattimer, J.K. \& Mc Coy, C. B.: J. Urol., 78, 662, 1957.

18) Edling, N.P.G.: Acta. Radiol., 32, 28, 1949.

19) Elliot, J.S.: J. Urol., 71, 49, 1954.

20）藤浪剛一：日泌尿会誌，6,47, 1918.

21) Forshall, I. \& Rickmann, P.P.: Brit. J. Urol., 25, 142, 1953.

22) Fischer, O.D. \& Forsythe, W.I.: Arch. Dis. Child., 39, 460, 1954.

23) Fulton, H.: Amer. J. Roentg., 78, 486, 1957.

24) Forsythe, W.I. \& Wealan, R.F.: Brit. J. Urol.. 30, 189, 1958.

25) Frain-Bell, L, \& Grieve, J. \& Pickard, C.: Brit. J. Urol., 31, 440, 1959.

26) Finlay, A.M.: Tex. St. J. Med., 53, 781, 1957. (Excepta. Med., 13, 381, 1959).

27) Graves, R.C. \& Davidoff, L.M.: J. Urol., 10, 185, 1923.

28) Graves, R.C. \& Davidoff, L.M.: J. Urol., 14, $1,1925$.

29) Gibson, H.M.: J. Urol., 62, 40, 1949.

30) 後藤荲: 泌尿紀要, 1. 196, 1953.

31) Guiley, H.A. \& Best, J.W.: J. Urol., 70, 884, 1953.

32) Gudbjerg, C.E. \& Hensen, L.K. \& Hasner, E.: Acta. Radiol., 50, 310, 1958.

33）羽太鋭治：日泌尿会誌，6，193，1917.

34) 日高誠一, 尾形一郎：日泌尿会誌, 14, 185, 1925.
35) Helmholz, H.F.: J. Urol., 31, 173, 1934.

36) Henningsen, O.: Zschr. Urol., 30, 772, 1936.

37）堀尾博：日泌尿会誌, 29, 941, 1940.

38）堀尾博：日泌尿会誌, 29, 968, 1940.

39）堀尾博：日泌尿会誌, 29, 984, 1940.

40）堀尾博：日泌尿会誌，29, 1049, 1940.

41）堀尾博：日泌尿会誌, 29, 1066, 1940.

42）堀尾博：日泌尿会誌， 29, 1080, 1940.

43) Hackworth, L.E.: J. Urol., 60, 947, 1948.

44) Hutch, J.A.: J. Urol., 68, 457, 1952.

45) Hutch, J.A. \& Bunge, R.G. \& Flocks, B.H.: J. Urol., 74, 607, 1955.

46) Hutch, J.A.: J. Urol., 85, 119, 1961.

47) Hodgkinson, C.P.: Amer. J. Obst. \& Gynec., 65, 560, 1953.

48) Hunter, D.T.: J. Urol., 71, 695, 1954.

49) Hanten, J.S. \& Galuszka, A.A. \& Rotner, M.: J. Urol., 82, 218, 1959.

50）市川篤二：綜合臨床，1３12，1952.

51）市川篤二 : 綜合臨床, 1, 535, 1952.

52) Johnson, S.H. \& Price, W.C.: Amer. J. Dis. Child., 78, 892, 1949.

53) Jeffcoate, T.N.A. \& Roberts, H.: Amer. J. Obst. \& Gynec., 64, 721, 1952.

54) Jannacone, G. \& Panzironi, P.E.: Acta. Radiol., 44, 451, 1955.

55) Jones, B.W. \& Headstream, J.W.: J. Urol., $80,114,1958$.

56）河野通成：日泌尿会誌，19，137, 1919.

57）木下秀一郎：日泌尿会誌，22，363，1922.

58) Kretschmer, H.L.: Surg. Gynec. \& Obst., 23, 709, 1916.

59) Kopsch, F.R.: Rauber-Kopsch, Lehrbuch und Atlas der Anatomie des Menschen, Georg Thieme-Leipzıg., 1948.

60）黒田恭一：日泌尿会誌，43，83，1953.

61）黒田恭一：日泌尿会誌, $47,711,1956$.

62）黒田恭一：日泌尿会誌, $52,729,1961$.

63) Kretschmer, H.L. \& Hibbs, W.G.: 78) より 引用.

64) Kjellberg, R. \& Ericsson, N.O. \& Rudhe, U.: The Lower Urinary Tract in Childhood, The Year Book Publishers Ins., 1957.

65）小見山茂人：日泌尿会誌， $49,821,1958$.

66) Lowsley, O.S. \& Kirwin, T.J.: Clinical Urology, The Williams \& Wilkins Co., 1956.

67) Levine, H.: 64）ょり引用.

68) Lattimer, J.K. \& Dean, A.L. \& Furey, C.A.: J. Urol., 76, 656, 1956.

69) Leuzinger, D.E. \& Lattimer, J.K. \& Mc Coy, C.B.: J. Urol., 82, 294, 1959.

70) Leadbetter, W.F.: J. Urol., 85, 119, 1961. 
71) Mc Fadden, G.D.C.: 109) ょり引用.

72）三矢辰雄 : 日泌尿会誌，25，441, 1936.

73) Muschat, M.: J. Urol., 30, 221, 1933.

74) Muellner, S.P.: Surg. Gynec. \& Obst., 88, 237, 1949.

75) Muellner, S.P. \& Fleischner, F.G.: J. Urol., 61, 233, 1949.

76) Morales, O. \& Romanus, R.: Acta. Radiol., $39, \quad 453,1953$.

77) Morales, O. \& Romanus, R.: J. Urol., 73, $162,1955$.

78) Martin, E.C. St. \& Gampbell, J.H. \& Pasquier, C.M.: J. Urol., 75, 151, 1956.

79) Marshall, V.F.: J. Urol., 85, 119, 1961.

80）尾形一郎：日泌尿会誌，17，424, 1928.

81) O’Brien, H.A. \& Mitchell, J.D.: J.A.M.A., 153, 1149, 1953.

82) Pasquier, C.M. \& Martin, E.C. St. \& Campbell, J.H.: J. Urol., 79, 41, 1958.

83) Rubin, A. \& Snoble, O.: Pediat. Listy, 8, 244, 1953.

84) Rothfeld, S.H. \& Epstein, B.S.: J. Urol., 78, 817, 1957.

85) Sgalitzer, M. \& Hrynstschak, Th: Zschr. Urol., 15, 399, 1921.

86) Stoeckel, W.: Z. urol. Chir., 16, 231, 1924.

87) Sienkiewicz, E.M.: Zschr. Urol., 31, 400, 1937.

88) Stockwell, L. \& Smith, C.K.: Amer. J. Dis. Child., 59, 1013, 1940.

89）佐藤誠：日泌尿会誌，29，447, 1940.

$90 ＼mathrm{~ 佐 藤 誠 ： 日 泌 尿 会 誌 ， 29 ， 565, ~} 1940$.

91）外塚岩太郎：綜合臨床，2，694，1953.
92) Stewart, C.M.: J. Urol., 74, 749, 1955.

93) Stewart, C.M.: J. Urol., 85, 119, 1961.

94) Spence, H.M.: J. Urol., 85, 119, 1961.

95）高木繁：皮尿誌， 11，409, 1911.

96) Tomas, B.A. \& Hubbel, R, J.: J, Urol., 26, 107, 1931.

97）田林綱太：日泌尿会誌，20，281, 1931.

98) Talbot, J.S. \& Bunts, R.C.: J. Urol., 61, 870, 1949.

99）高安久雄, 西浦常雄 : 日泌尿会誌, 44, 123, 1953.

100）高安久雄, 西浦常雄：日泌尿会誌, 45, 159, 1954.

101）辻一郎, 斯波光生, 小西武彥 : 治療, 39, 1220, 1957.

102) Uson, A.C. \& Johnson, D.W. \& Lattimer, J. K. \& Melicow, M.M.: Amer. J. Roentg., 80, $590,1958$.

103) Vulliamy, D.: Arch. Dis. Child., 31, 439, 1956.

104) Van Duzen, R.E.\& Duncan, I.G.: J.A.M.A., 153, 1345, 1953.

105) Vernet, G.: Zschr. Urol., 53, 181, 1960.

106) Wesson, M.B.: J. Urol., 4, 279, 1920.

107) Winsbury-White, H.P.: Brit. J. Urol., 13, $149,1941$.

108) Weens, H.S. \& Rohrer, R.H. \& Youmans, H.D.: J. Urol., 81, 232, 1959.

109) Williams, I.: Urology in Childhood, Springer Verlag., 1958.

110）山際義秀：日泌尿会訫，45，653, 1954.

111）山本祳：日泌尿会誌，50, 555, 1959. 